SJ Quinney College of Law, University of Utah Utah Law Digital Commons

Utah Law Faculty Scholarship

Utah Law Scholarship

$1-1-2017$

\title{
The Control of Air Pollution on Indian Reservations
}

Arnold W. Reitze Jr.

S.J. Quinney College of Law, University of Utah

Follow this and additional works at: http://dc.law.utah.edu/scholarship

\section{Recommended Citation}

Reitze, Arnold W. Jr., "The Control of Air Pollution on Indian Reservations" (2017). Utah Law Faculty Scholarship. 4. http://dc.law.utah.edu/scholarship/4

This Article is brought to you for free and open access by the Utah Law Scholarship at Utah Law Digital Commons. It has been accepted for inclusion in Utah Law Faculty Scholarship by an authorized administrator of Utah Law Digital Commons. For more information, please contact valeri.craigle@law.utah.edu. 


\title{
The Control of Air Pollution on Indian Reservations
}

\author{
(C) Arnold W Reitze, Jr.* \\ October 7, 2016 \\ arnold.reitze@law.utah.edu
}

Professor of Law, The University of Utah, member of the Utah Air Quality Board. Research assistance was provided by J.D. candidate Sheena Christman. This research was supported by the Albert and Elaine Borchard Fund for Faculty Excellence. The author wishes to thank John Ruple, Esq. and Dean Suagee, Esq.for their helpful comments.

\section{Table of Contents}

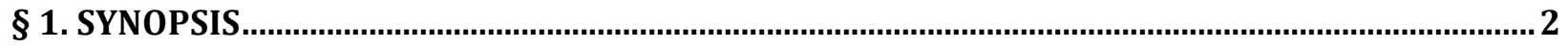

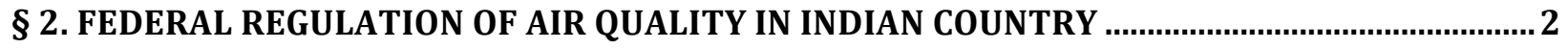

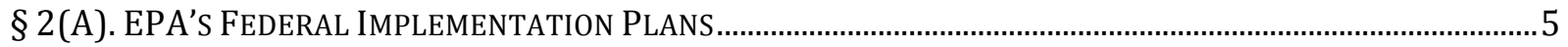

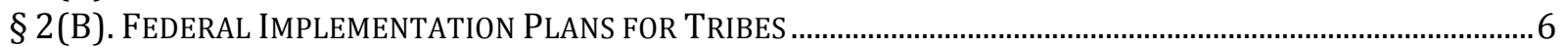

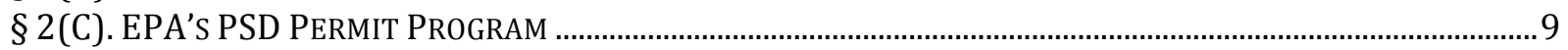

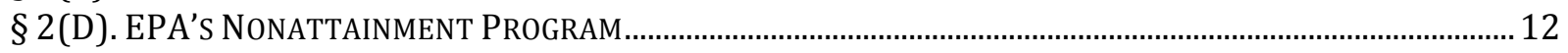

$\S$ 2(E). EPA'S OPERATING PERMIT PROGRAM ............................................................................................... 16

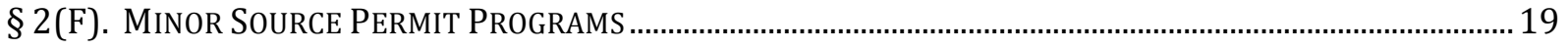

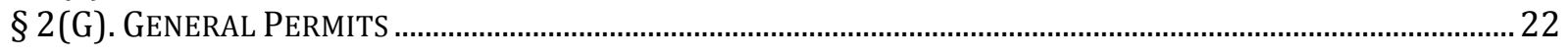

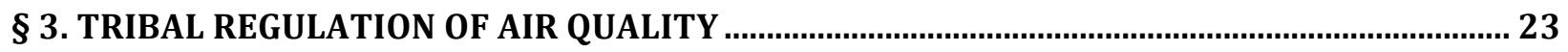

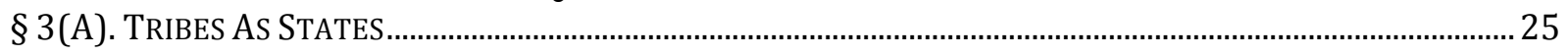

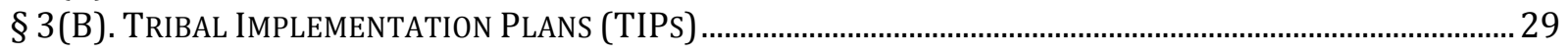

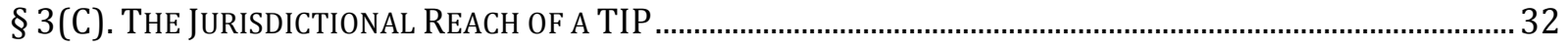

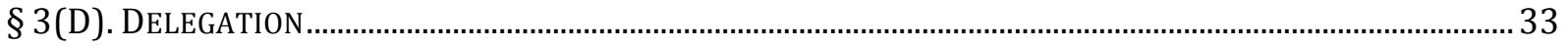

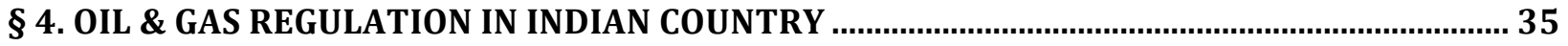

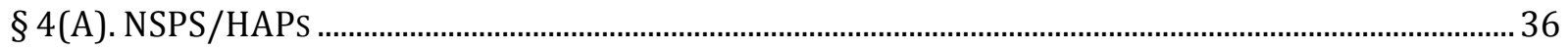

$\S 4(B)$. OIL AND NATURAL GAS SECTOR: EMISSION STANDARDS FOR NEW AND MODIFIED SOURCES................ 38

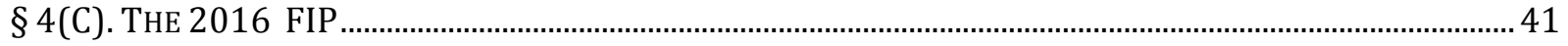

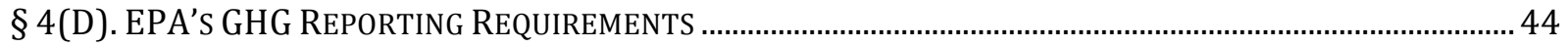

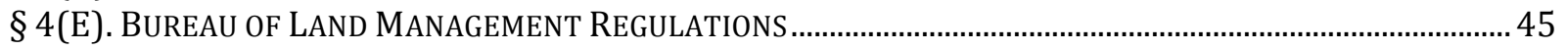

§ 5. AIR POLLUTION CONTROL IN UTAH'S INDIAN COUNTRY ....................................................... 46

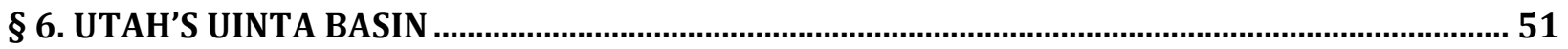

§ 7. CONCLUSION 


\section{$\S 1$. Synopsis}

Changes in oil and gas production technology in recent years led to a boom in domestic oil and gas production. Between 2010 and 2014 petroleum production increased fifty-nine percent and natural gas production increased by twenty-two percent. ${ }^{1}$ While this production has reduced the nation's dependence on imported fuel it has resulted in serious air pollution problems developing in rural areas of the western United States including Indian lands. The lack of effective air pollution controls on existing oil and gas well operations has made it difficult to control emissions from this industry. This article looks at the efforts being made to deal with air quality issues arising in Indian country that involve a legal regimen that differs from the program applicable to the rest of the nation. It examines the application of air pollution controls in Utah where approximately forty percent of the active oil and gas wells are located in Indian reservations. ${ }^{2}$

\section{§ 2. Federal Regulation of Air Quality in Indian Country}

Indian lands in 2014 produced 1.8 percent of U.S. crude oil, 0.4 percent of the natural gas liquids, and 1.0 percent of the natural gas production. ${ }^{3}$ Royalty income from energy and mineral resources in 2015 is projected to exceed $\$ 1$ billion, and is the largest source of revenue generated from Indian Trust lands. ${ }^{4}$ Moreover, the energy industry is a major source of employment responsible for an estimated 96,080 jobs. ${ }^{5}$ Because energy production from Indian lands is concentrated in the West, the local economic benefits are significant. Nevertheless, some Indian officials believe onerous restrictions by the Bureau of Land Management (BLM) are responsible for the relatively small percentage of domestic production from Indian lands. ${ }^{6}$ Regardless of whether changes in regulations would increase production, the current level of oil and gas production in Indian country is contributing to high concentrations of ambient ozone that threatens public health and the environment. ${ }^{7}$

\footnotetext{
${ }^{1}$ U.S. Energy Information Administration, U.S. Field Production of Crude Oil (Dec. 31, 2015); U.S. Energy Information Administration, U.S. Natural Gas Marketed Production (Dec. 31, 2015).

${ }^{2}$ Well Counts, UTAH OIL \& GAS HOME, http://oilgas.ogm.utah.gov/Statistics/Well_counts.cfm (last visited Feb. 4 , 2016); Utah Division of Environmental Quality, Uinta Basin, Ozone in the Uinta Basin (2015).

${ }^{3}$ U.S. ENERgy INFO. Admin., SAlES OF Fossil Fuels PRODUCED FROM FEDERAL AND INDiAN LANDS FY 2003 THROUGH FY 2014, at 3 tbl.2 (2015), http://www.eia.gov/analysis/requests/federallands/pdf/eia-federallandsales.pdf.

${ }^{4}$ U.S. BuREAU OF INDIAN AFFAIRS, OIL AND GAS OUTLOOK IN INDIAN COUNTRY 1 (2015), http://www.bia.gov/cs/groups/xieed/documents/document/idc1-024535.pdf.

${ }^{5}$ Id. at 6.

${ }^{6}$ John Kemp, Tribes Call for Faster Drilling on Indian lands, REUTERS (Feb. 5. 2013), http://www.reuters.com/article/column-kemp-oilgas-indian-lands-idUSL5N0B5A9W20130205.

${ }^{7}$ See infra $\$ 5$.
} 
Indian tribes have inherent sovereignty under the U.S. Constitution. ${ }^{8}$ Nevertheless, they are considered domestic dependent nations, and the Federal government is the trustee, which results in the Environmental Protection Agency (EPA) playing an important role in regulating air pollution in Indian country. ${ }^{9}$ The present federal policy is to encourage Indian tribes to manage their land and resources, ${ }^{10}$ subject to restrictions imposed by Congress. ${ }^{11}$

The United States government is the trustee for the 566 tribal entities in the forty-eight contiguous states and Alaska that are recognized by the U.S. Bureau of Indian Affairs. A large number of the tribes are in Alaska because each native village is considered a tribal entity. ${ }^{12}$ An Indian tribe "means an Indian or Alaska Native tribe, band, nation, pueblo, village, or community that the Secretary of the Interior acknowledges to exist as an Indian tribe pursuant to the Federally Recognized Indian Tribe List Act of 1994." 13 Indian tribes control approximately 326 land areas, which encompass over 56 million acres of Indian reservations. ${ }^{14}$ There are over 300 Indian reservations in the continental United States. ${ }^{15}$ The largest reservation is the Navajo Nation with more than 16 million acres in Arizona, New Mexico, and Utah. Many reservations, however, are less than 100 acres. ${ }^{16}$

"Indian reservation" as used in this article corresponds to the first prong of the term "Indian country" as defined in 18 U.S.C. $§ 1151$, i.e., "all land within the limits of any Indian reservation." 17 Tribal jurisdiction is complicated. Tribes have inherent sovereignty over their members and their territory, generally do not have criminal jurisdiction over non-Indians, and

\footnotetext{
${ }^{8}$ U.S. Const. art.1, § 8, cl.3; see Worcester v. Georgia, 31 U.S. (6 Pet.) 515 (1832); United States v. Wheeler, 435 U.S. 313, 322-23 (1978); Alex Tallchief Skibine, Tribal Sovereign Interests Beyond the Reservation Borders, 12 LEWIS \& CLARK L. REV. 1003 (2008).

${ }^{9}$ Cherokee Nation v. Georgia, 30 U.S. 1 (1831). For a critique of this trust relationship, see Alex T. Skibine, Using the New Equal Protection to Challenge Federal Control Over Tribal Lands, 36 PUB. LAND \& RESOURCES L. REV. 3 (2015); Heather Whitney-Williams \& Hillary M. Hoffmann, Fracking in Indian Country: The Federal Trust Relationship, Tribal Sovereignty, and the Beneficial Use of Water. 32 YALE J. ON REG. 451 (2015).

${ }^{10}$ New Mexico v. Mescalero Apache Tribe, 462 U.S. 324, 335 (1983); MacArthur v. San Juan County, 391 F. Supp. 2d 895, 941 (D. Utah 2005).

${ }^{11}$ United States v. Kagama, 118 U.S. 375 (1886).

12 Indian Entities Recognized and Eligible To Receive Services From the United States Bureau of Indian Affairs, 80 Fed. Reg. 1942 (Jan. 14, 2015).

${ }^{13}$ Consultation and Coordination with Indian Tribal Governments, Exec. Order No. 13,175, 65 Fed. Reg. 67,249 (Nov. 9, 2000); see United States v. Sandoval, 231 U.S. 28, 48 (1913) (Pueblo that held land with communal title was held to be a dependent community).

${ }^{14}$ Frequently Asked Questions, U.S. DEP'T INTERIOR, http://www.bia.gov/FAQs/ (last visited Oct. 28, 2015).

${ }^{15}$ Reservations $A$ to $Z$, AAANATIVEARTS.COM, http://www.aaanativearts.com/reservations-a-to-z\#axzz40drSAH8G (last visited Oct. 28, 2015) (providing an alphabetical list of U.S. Indian reservations).

${ }^{16}$ Id. For a map of Indian reservations in the continental United States, see Indian Reservations in the Continental United States, NAT'L NAGPRA, www.nps.gov/NAGPRA/DOCUMENTS/ResMAP.HTM (last visited Oct. 28, 2015).

${ }^{17}$ For an explanation of the different terminology, see Julie M. Reding, Comment, Controlling Blue Skies in Indian Country: Who is the Air Quality Posse-Tribes or States? The Applicability of the Clean Air Act in Indian Country and on Oklahoma Tribal Lands, 18 AM. IND. L. REV. 161, 184 n.174-76 (1993); see also Ute Indian Tribe v. Utah Ute Indian Tribe I, 521 F. Supp. 1072, 1082 (D. Utah 1981).
} 
generally do not have civil authority over the conduct of nonmembers of the tribe on non-trust land within reservation boundaries, except that tribes may have authority to regulate the conduct of nonmembers who have consensually entered into commercial dealings with the tribe or whose conduct threatens the political integrity, economic security, or health or welfare of the tribe. ${ }^{18}$ However, an Indian tribe has very limited authority to regulate the conduct of non-Indians occurring outside reservation boundaries. ${ }^{19}$ States generally do not have authority to implement environmental protection laws in Indian country. ${ }^{20}$

Determining what constitutes Indian country can be challenging. For example, on October 30, 2001, the D.C. Circuit defined Indian lands as land validly set apart for the use of Indians under the superintendence of the Government. ${ }^{21}$ The U.S. Court of Appeals for the District of Columbia Circuit in 2014 vacated the definition of Indian country with respect to non-reservation areas of Indian country (i.e., dependent Indian communities and Indian allotments). ${ }^{22}$ The court held that the states, not tribes or the EPA, have initial primary responsibility for implementation plans under the Clean Air Act's (CAA) section 110 in non-reservation areas of Indian country in the absence of a demonstration of tribal jurisdiction by the EPA or a tribe. ${ }^{23}$ The EPA is in the process of amending its regulation to be

\footnotetext{
${ }^{18}$ Montana v. United States, 450 U.S. 554, 565 (1981). See generally COHEN's HANDBOOK OF FEDERAL INDIAN LAW $\S 10.03$ (2012 ed.).

${ }^{19}$ William C. Scott, Tribal Management of Tribal Lands and Resources: Environmental Regulation, 52 RoCKY MTN. Min. L. Found. J. 25, 29 (2015); Alex Skibine, supra note 8.

${ }^{20}$ COHEN'S HANDBOOK OF FEDERAL INDIAN LAW, $\S 10.02$.
}

${ }^{21}$ Michigan v. EPA, 268 F.3d 1075 (D.C. Cir. 2001).

${ }^{22}$ Oklahoma Dept. of Environmental Quality v. EPA, 740 F.3d 185 (Jan. 17, 2014).

${ }^{23}$ Id. 
consistent with the court's decision. ${ }^{24}$ Moreover, over time the boundaries of reservations change. For example, the Ute Indian Tribe in Utah occupies the Uintah and Ouary Reservation. Its exterior boundary is defined by the original boundaries of the Uintah Valley Reservation and the addition of the Uncompahgre Reservation and the Hill Creek Extension. However, the land within the reservation has been reduced by allotments of land, particularly the General Allotment Act of 1887,25 as well as other federal actions including the 1905 National Forest withdrawals. ${ }^{26}$ Moreover, there are four categories of non-trust lands within the reservations. ${ }^{27}$ This has resulted in years of litigation over which lands within the exterior boundaries of the reservation are Indian lands. ${ }^{28}$ In June 2016 the State of Utah, two Utah counties and the Ute Indian Tribe announced agreements concerning tribal and state jurisdiction. There will be cross-deputization of state, local and tribal police, but the Tribal Court will not exercise civil and regulatory authority over reservation lands owned by nonmembers, which will include environmental regulation. ${ }^{29}$ However, this agreement does not affect the EPA, which has primary jurisdiction over environmental regulation on Indian reservations.

\section{§ 2(A). EPA's Federal Implementation Plans}

The EPA administers the CAA, which since 1970 has been the primary legal authority for administering and enforcing air pollution control requirements. The CAA requires each state to submit and receive the EPA's approval of a state implementation plan (SIP) to control stationary sources. ${ }^{30}$ If there is not an approved SIP, the EPA is to develop and implement a federal implementation plan (FIP). ${ }^{31}$ By the late 1970s, the EPA's position was the states do not have authority to implement environmental protection laws in Indian country within the state. ${ }^{32}$ The EPA's position was upheld in 1985 when the Ninth Circuit held the State of Washington could not administer a hazardous waste program under the Resource Conservation and Recovery Act (RCRA)

\footnotetext{
${ }^{24}$ See e.g., 80 Fed. Reg. 56,554, 56,566 (Sept. 18, 2015)

25 U.S.C. $\$ \S 331-34,339,341-42,348-49,354,381$ (2012).

${ }^{26}$ Heather J. Tanana \& John C. Ruple, Energy Development in Indian Country: Working Within the Realm of Indian Law and Moving Towards Collaboration, 32 UTAH ENVTL. L. REV. 1, 11 (2012). Allocations to non-Indians ended in 1934, but by then landholding by Indians in the United States had been reduced by 86 million acres. Jana B. Milford, Tribal Authority under the Clean Air Act: How Is It Working?, 42 CoL. LAw 213, 217 (2013).

${ }^{27}$ Ute Indian Tribe v. Utah (Ute v. Utah), 114 F.3d 1513, 1529 (10th Cir. 1997). The four categories of non-trust lands involve lands transferred under allotment legislation during 1902-1905; land apportioned under 1954 legislation; lands allocated to individual Indians that passed into fee status after 1905; and lands consolidated pursuant to 1934 and 1983 legislation.

${ }^{28}$ Id. See e.g. Ute Indian Tribe of the Uintah and Ouray Reservation v. Myton, 2016 WL 4191388 (10 ${ }^{\text {th }}$. Cir. Aug. 9, 2016).

${ }^{29}$ Tom Harvey, State, counties have reached jurisdictional deals with Utes, SALT LAKE TRIB. . June 15, 206 , at B5.

${ }^{30}$ CAA $\S 110(\mathrm{k}), 42$ U.S.C. $\$ 7410(\mathrm{k})$.

${ }^{31}$ CAA $\S 110(\mathrm{c}), 42$ U.S.C. $\S 7410(\mathrm{c})$.

${ }^{32}$ Scott, supra note 19 , at 33 .
} 
on lands within Indian reservations. ${ }^{33}$ Numerous court decisions support the position that an approved state air pollution control program does not apply to Indian country within the state. ${ }^{34}$

Indian tribes have the opportunity to administer the CAA's programs but few tribes have accepted this responsibility, thus primary regulatory authority for air pollution control in Indian country is usually based on the EPA's regulations, which includes FIPs. ${ }^{35}$ There are currently forty-four FIPs applicable to specific tribes. One FIP has been issued by the EPA's Region 8, headquartered in Denver, but there is no FIP for any tribe in Utah because no Indian reservation is in a designated nonattainment area. This may change in the near future for the Ute Reservation, discussed in $\S 5$ infra. Even in the absence of a FIP, major sources located within Indian reservations are usually subject to the EPA's regulations including national FIPs such as the FIP for New Source Review in Indian Country, discussed below. ${ }^{36}$ Executive Order 13,175 requires the EPA to consult and coordinate with tribal governments on federal actions that impact tribes. ${ }^{37}$ Pursuant to this Executive Order and a Memorandum from President Obama, ${ }^{38}$ on May 4, 2011, the EPA updated its policy on consultation and coordination, to ensure tribe members have significant opportunities to participate in the regulatory process even if their tribe has not assumed regulatory jurisdiction. ${ }^{39}$

\section{§ 2(B). Federal Implementation Plans for Tribes ${ }^{40}$}

\section{Region 1}

1. Mohegan Tribe of Indians, Connecticut

\footnotetext{
${ }^{33}$ Wash. Dep't of Ecology v. EPA, 752 F.2d 1465 (9th Cir. 1985).

${ }^{34}$ Ariz. Pub. Serv. Co. v. EPA, 211 F.3d 1280 (D.C. Cir. 2000), cert. denied sub nom, Michigan v. EPA, 532 U.S. 970 (2001); Alaska v. Native Village of Venetie Tribal Gov’t, 522 U.S. 520, 527 fn.1 (1998); California v. Cabazon Band of Mission Indians, 480 U.S. 202, 216 \& n.18 (1987).

${ }^{35}$ Cabazon Band of Mission Indians, 480 U.S. at 216 \& fn. 18 . The Safe, Accountable, Flexible, Efficient Transportation Equity Act of 2005 (SAFETEA) contains section 10,211 relating to implementation of environmental regulatory programs under Federal environmental laws in Indian country in Oklahoma. However, neither the State of Oklahoma, nor any Indian Tribe in Oklahoma, applied to administer the CAA program in Indian country. Therefore, FIPs apply throughout Indian country, including Indian country in Oklahoma. U.S. Envtl. Protection Agency, Review of New Sources and Modifications in Indian Country, 76 Fed. Reg. 38,748, 38,778 (July 1, 2011 ).

${ }^{36}$ The new source review program includes a prevention of significant deterioration (PSD) program for areas that meet national ambient air quality standards (NAAQS) and a new source review (NSR) program in areas that do not meet the NAAQS. The use of the term NSR for two purposes can be confusing.

${ }^{37}$ Exec. Order No. 13,175, supra note 13.

3874 Fed. Reg. 57,881 (Nov. 9, 2009).

${ }^{39}$ EPA POLICY ON CONSUltation AND COORDINATION With INDIAN TRIBEs (May 4, 2011), http:/www.epa.gov/sites/production/files/2013-08/documents/cons-and-coord-with-indian-tribes-policy.pdf.

4070 Fed. Reg. 18,113 (Apr. 8, 2005).
} 
74 Fed. Reg. 49,327 (Sept. 29, 2009).

\section{Region 2}

2. Saint Regis Mohawk Tribe, 72 Fed. Reg. 69,618 (Dec. 10, 2007).

\section{Region 8}

3. Fort Berthold Indian Reservation (Mandan, Hidatsa and Arikara Nation), North Dakota 78 Fed. Reg. 17,858 (Mar. 22, 2013).

\section{Region 9}

4. Gila River Indian Community

76 Fed. Reg. 17030 (Mar. 28, 2011).

5. Pechanga Band of Luiseno Mission Indians of the Pechanga Reservation 80 Fed. Reg. 18,130 (Apr. 3, 3015).

\section{Region 10}

6. Burns Paiute Tribe of the Burns Paiute Indian Colony of Oregon 70 Fed. Reg. 18,110 (Apr. 8, 2005).

7. Confederated Tribes of the Chehalis Reservation, Washington 70 Fed. Reg. 18,110 (Apr. 8, 2005).

8. Coeur D'Alene Tribe of the Coeur D'Alene Reservation, Idaho 70 Fed. Reg. 18,110 (Apr. 8, 2005).

9. Confederated Tribes of the Colville Reservation, Washington 70 Fed. Reg. 18,110 (Apr. 8, 2005).

10. Confederated Tribes of the Coos, Lower Umpqua and Siuslaw Indians of Oregon 70 Fed. Reg. 18,112 (Apr. 8, 2005).

11. Coquille Tribe of Oregon

12. Cow Creek Band of Umpqua Indians of Oregon 70 Fed. Reg. 18,113 (Apr. 8, 2005).

13. Confederated Tribes of the Grand Ronde Community of Oregon 70 Fed. Reg. 18,114 (Apr. 8, 2005).

14. Hoh Indian Tribe of the Hoh Indian Reservation, Washington 70 Fed. Reg. 18,114 (Apr. 8, 2005). 
15. Jamestown S'Klallam Tribe of Washington

70 Fed. Reg. 18,115 (Apr. 8, 2005).

16. Kalispel Indian Community of the Kalispel Reservation

70 Fed. Reg. 18,116 (Apr. 8, 2005).

17. Klamath Indian Tribe of Oregon

70 Fed. Reg. 18,116 (Apr. 8, 2005).

18. Kootenai Tribe of Idaho

70 Fed. Reg. 18,117 (Apr. 8, 2005).

19. Lower Elwha Tribal Community of the Lower Elwha Reservation, Washington 70 Fed. Reg. 18,117 (Apr. 8, 2005).

20. Lummi Tribe of the Lummi Reservation, Washington

70 Fed. Reg. 18,118 (Apr. 8, 2005).

21. Makah Indian Tribe of the Makah Indian Reservation, Washington

70 Fed. Reg. 18,119 (Apr. 8, 2005).

22. Muckleshoot Indian Tribe of the Muckleshoot Reservation, Washington

70 Fed. Reg. 18,119 (Apr. 8, 2005).

23. Nez Perce Tribe of Idaho

70 Fed. Reg. 18,120 (Apr. 8, 2005).

24. Nisqually Indian Tribe of the Nisqually Reservation, Washington

70 Fed. Reg. 18,120 (Apr. 8, 2005).

25. Nooksack Indian Tribe of Washington

70 Fed. Reg. 18,121 (Apr. 8, 2005).

26. Port Gamble Indian Community of the Port Gamble Reservation, Washington 70 Fed. Reg. 18,122 (Apr. 8, 2005).

27. Puyallup Tribe of the Puyallup Reservation, Washington 70 Fed. Reg. 18,122 (Apr. 8, 2005).

28. Quileute Tribe of the Quileute Reservation, Washington 70 Fed. Reg. 18,123 (Apr. 8, 2005).

29. Quinault Tribe of the Quinault Reservation, Washington 70 Fed. Reg. 18,123 (Apr. 8, 2005).

30. Sauk-Suiattle Indian Tribe of Washington

70 Fed. Reg. 18,124 (Apr. 8, 2005).

31. Shoalwater Bay Tribe of the Shoalwater Bay Indian Reservation, Washington 
70 Fed. Reg. 18,125 (Apr. 8, 2005).

32. Shoshone-Bannoc Tribes of the Fort Hall Indian Reservation of Idaho 70 Fed. Reg. 18,125 (Apr. 8, 2005).

33. Confederated Tribes of the Siletz Reservation, Oregon 70 Fed. Reg. 18,126 (Apr. 8, 2005).

34. Skokomish Indian Tribe of the Skokomish Reservation, Washington 70 Fed. Reg. 18,126 (Apr. 8, 2005).

35. Spokane Tribe of the Spokane Reservation, Washington 70 Fed. Reg. 18,127 (Apr. 8, 2005).

36. Squaxin Island Tribe of the Squaxin Island Reservation, Washington 70 Fed. Reg. 18,128 (Apr. 8, 2005).

37. Stillaguamish Tribe of Washington 70 Fed. Reg. 18,128 (Apr. 8, 2005).

38. Suquamish Indian Tribe of the Port Madison Reservation, Washington 70 Fed. Reg. 18,129 (Apr. 8, 2005).

39. Swinomish Indians of the Swinomish Reservation, Washington 70 Fed. Reg. 18,129 (Apr. 8, 2005).

40. Tulalip Tribes of the Tulalip Reservation, Washington 70 Fed. Reg. 18,130 (Apr. 8, 2005).

41. Confederated Tribes of the Umatilla Reservation, Oregon 70 Fed. Reg. 18,130 (Apr. 8, 2005).

42. Upper Skagit Indian Tribe of Washington 70 Fed. Reg. 18,131 (Apr. 8, 2005).

43. Confederated Tribes of the Warm Springs Reservation of Oregon 70 Fed. Reg. 18,132 (Apr. 8, 2005).

44. Confederated Tribes and Bands of the Yakima Nation, Washington 70 Fed. Reg. 18,132 (Apr. 8, 2005).

See 40 C.F.R. Part 49, Subparts D-M for more details.

\section{$\S 2(C)$. EPA's PSD Permit Program}

Areas having better air quality than the national ambient air quality standards (NAAQS) are subject to the CAA's Prevention of Significant Deterioration (PSD) 
program. ${ }^{41}$ A new major emitting facility subject to the PSD program must obtain a preconstruction permit that includes the requirement to use the Best Available Control Technology (BACT). ${ }^{42}$ Construction is defined to include major modifications, ${ }^{43}$ if there is a significant emissions increase. ${ }^{44}$ Significant is defined in terms of tons per year. ${ }^{45} \mathrm{~A}$ modification is any physical or operational change that would cause an increase in the allowable emissions of a minor source or an increase in the actual emissions of a major source for any regulated NSR pollutant or that would cause the emission of any regulated NSR pollutant not previously emitted. ${ }^{46}$ The following exemptions apply: routine maintenance, repair or replacement; an increase in the hours of operation or in the production rate; a change in ownership at a stationary source; and activities listed in 40 C.F.R. $§ 49.153(\mathrm{c}) .^{47} \mathrm{~A}$ major modification requires an increase in actual emissions based on the actual-to-projected-actual test. ${ }^{48}$ For a source that is a major source for hazardous air pollutants (HAPs), CAA $\S 112(\mathrm{~g})(2)(B)$ provides that you may not construct or reconstruct a major source of HAPs unless the appropriate permitting authority determines that the maximum available control technology (MACT) requirements for new sources will be met. If the Administrator has not established a MACT standard for the source category, MACT is to be determined on a case-by-case basis. ${ }^{49}$

A permit applicant must analyze the impact of the project on ambient air quality to assure there will be no violation of the NAAQS, the PSD increments, or visibility protection requirements. ${ }^{50}$ Sources or modifications that impact Class I areas (e.g., national parks and other public lands) may have additional requirements to protect air quality related values (AQRVs). ${ }^{51}$ Under the PSD program, if the source's potential to emit is greater than the major source threshold for one pollutant, then all pollutants regulated by the CAA are subject to control. However these additional pollutants are subject to control only if their potential emissions are above the level defined as "significant" in the PSD regulations, which is significantly lower than the major modification threshold. ${ }^{52}$

No tribe was administering an EPA-approved PSD program in 2011.53 On July 1 , 2011, the EPA promulgated regulations that included sources in Indian country in its

\footnotetext{
${ }^{41} 42$ U.S.C. $\S \S 7470,7471$ (2012).

4240 C.F.R. § 52.21(b)(12) (2015); 76 Fed. Reg. 38,748 (July 1, 2011).

${ }^{43}$ CAA $\S 169(2)(C), 42$ U.S.C. $\S 7479(2)(C)$.

${ }^{44} 40$ C.F.R. $\S 52.21$ (a)(2)(iv).

4540 C.F.R. $\S 52.21(\mathrm{~b})(23)$.

4676 Fed. Reg. 38,748, 38,756 (July 1, 2011).

${ }^{47} \mathrm{Id}$.

${ }^{48}$ State of New York v. EPA, 413 F.3d 3, 23-27 (D.C. Cir. 2005).

4976 Fed. Reg. at 38,771.

${ }^{50} 42$ U.S.C. $\S 7475$ (a) (2012). An increment is a limit on the amount of increase in the atmospheric concentration of a specific pollutant that is allowed.

${ }^{51} 42$ U.S.C. $\S 7475(\mathrm{a})(5)$.

5276 Fed. Reg. at 38,755.

5376 Fed. Reg. at 38,753, 38,778.
} 
PSD program. ${ }^{54}$ The EPA's implementation of the CAA in Indian country continues until there is an EPA-approved tribal implementation plan (TIP) or an approved program delegation. ${ }^{55}$ The EPA's Region 8 has issued 14 PSD permits. ${ }^{56}$

To address the impairment of visibility, the 1990 CAA Amendments added additional requirements to the PSD program. ${ }^{57}$ The Amendments mandated the creation of the Grand Canyon Visibility Transport Commission (GCVTC) to address the problem of air pollution in the Grand Canyon National Park. ${ }^{58}$ The GCVTC included representatives from eight western states and the Pueblo of Acoma, the Hopi Tribe, the Hualapai Tribe, and the Navajo Nation. The Commission's recommendations were incorporated into EPA's Regional Haze Rule. ${ }^{59}$ Subsequently, the GCVTC was replaced by the Western Regional Air Partnership (WRAP), which has an expanded membership that includes the nine western states and the following Indian tribes: the Campo Tribe (California), Confederated Tribes of Salish and Kootenai (Montana), Cortina Indian Rancheria (California), Hopi Tribe (Arizona), Hualapal Nation of the Grand Canyon (Arizona) Nez Perce Tribe (Idaho), Northern Cheyenne Tribe (Montana), Pueblo of Acoma (New Mexico), Pueblo of San Felipe (New Mexico), Shoshone-Bannock Tribes of Fort Hall (Idaho), Orutsararmiut Native Council (Alaska), and Pueblo of Zuni (New Mexico). ${ }^{60}$

In 2000 WRAP submitted an annex to implement the GCVTC recommendations and to meet the requirements of the Regional Haze Rule. The annex included a plan that applied through 2018 that involved a declining emissions cap and a sulfur dioxide trading program. The area covered by the annex includes 200 tribes, and four tribes have or had major sources of sulfur dioxide emissions within their reservations. The sources are the Navajo Nation's Four Corners Power Plant and the Navajo Generating Plant, the Shoshone-Bannock Tribe's Fort Hall Reservation Astaris-Idaho phosphorous plant (now closed), the Wind River Reservation Snyder Oil and Koch Sulfur Products facilities, and the Ute Indian Tribe of the Uintah and Ouray Reservation Bonanza Power Plant (now in the process of reducing operations). ${ }^{61}$

The Four Corners Power Plant, near Shiprock, New Mexico, was granted a 25-year extension of its lease with the Navajo Nation on July 17, 2015. However, three of its five units shut down, and the other two units agreed to install selective catalytic reduction devices. ${ }^{62}$ On June 24, 2015, the utility companies that own the Four Corners Power Plant, in a settlement with the Department of Justice, agreed to install upgraded $\mathrm{SO}_{2}$ and $\mathrm{NO}_{x}$ pollution

${ }^{54} I d$.

${ }^{55}$ Id.at 38,779 .

${ }^{56}$ U.S. Envtl. Protection Agency, CAA Permits Issued by EPA in Region (Aug. 28, 2015).

${ }^{57}$ CAA $\S 169 B, 42$ U.S.C. $\$ 7492$.

${ }^{58}$ CAA $\S 169 B(f), 42$ U.S.C. $\S 7492(f)$.

${ }^{59}$ U.S. Envtl. Protection Agency, Regional Haze Regulations, 64 Fed. Reg. 35,714 (July 1, 1999).

${ }^{60}$ WRAP Board: Members, WESTERN REGIONAL AIR PARTNERSHIP, http://www.wrapair.org/WRAP/members.html (last visited Oct. 25, 2015).

${ }^{61}$ Brian Maffly, Settlement: “Early retirement' for Utah power plant?, SALT LAKE TRIB., Oct. 7, 2015 , at A1.

${ }^{62}$ William H. Carlile, Interior's Record of Decision Grants Extension to Navajo Power Plant, Mine, 46 ENV'T REP. (BNA) 2209 (July 23, 2015). 
controls at an estimated cost of $\$ 160$ million. The settlement also requires improvements to meet the regional haze program. In addition, the settlement requires over $\$ 10$ million to be spent on heath and welfare projects to benefit the local residents. ${ }^{63}$ Moreover, both the Navajo Generating Station and the Four Corners Power Plant are required by the Clean Power Plan to reduce carbon dioxide emissions, ${ }^{64}$ when and if it is allowed to be implemented. ${ }^{65}$

The recommendations of the GCVTC were the basis for Utah's 2003 regional haze SIP. This SIP was modified September 3, 2008 to include Best Available Retrofit Requirements (BART) applicable to two coal-fired power plants. ${ }^{66}$ On December 14, 2012, EPA approved most of Utah's Regional Haze SIP, but disapproved the BART determination. Prior to EPA's disapproval three of the four units had already installed the BART required equipment and the fourth unit installed the required controls in 2014 as required by state law. ${ }^{67}$ Utah then opted to develop a $\mathrm{NO}_{\mathrm{x}}$ control program based on the alternative to BART provision provided by 40 C.F.R. $\S 51.308(\mathrm{e})(2)$. The revised SIP provision was approved by the Air Quality Board in June 2015 and sent to the EPA for its approval. The Regional Haze SIP revision remains controversial as environmentalists continue to press for selective catalytic reduction technology being required for Rocky Mountain Power's Hunter and Huntington plants. On January 14, 2016, the EPA partially approved and partially disapproved Utah's implementation plan for the haze rule and called for a new public hearing. ${ }^{68}$ On July 5, 2016, the EPA published its final rule that partially approved Utah's $\mathrm{PM}_{10}$ portion of its haze SIP,

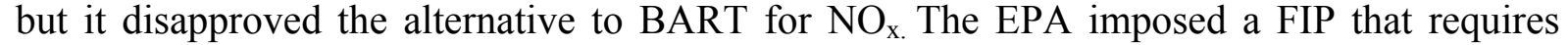
Selective Catalytic Reduction technology to be installed on units one and two at the Hunter and Huntington power plants by $2021 .^{69}$

\section{§ 2(D). EPA's Nonattainment Program}

In nonattainment areas new source review (NSR) requirements are applicable to major sources, which are those that have emissions of 100 tons per year (tpy) of any pollutant subject to regulation under the Act (except greenhouse gases) or lesser

\footnotetext{
${ }^{63}$ U.S. Dept. of Justice, U.S. Requires Arizona and New Mexico Plant Owners to Reduce Emissions at Navajo Nation Four Corners Power Plant (June 24, 2015).

${ }^{64}$ U.S. Envtl. Protection Agency, Carbon Pollution Emission Guidelines for Existing Stationary Sources: Electric Utility Generating Units, 80 Fed. Reg. 64,662 (Oct. 23, 2015).

${ }^{65}$ The Clean Power Plan is being challenged by 27 states as well as several utilities and industry groups. West Virginia v. EPA, D.C. Cir. No. 15-1363. On February 9, 2016, the U.S. Supreme Court ordered that action on the Plan be halted until the case is decided by the Court of Appeals for the D.C.Circuit. No.15A 773 (Feb. 9, 2016). The case is scheduled for oral arguments on September 27, 2016.

${ }^{66}$ Utah Division of Air Quality, Staff Review 2008 PM BART Determination and Recommended Alternative to BART for $N O_{x}$ (May 13, 2015).

${ }^{67} I d$. at 5 .

${ }^{68}$ U.S. Envtl. Protection Agency, Approval, Disapproval and Promulgation of Air Quality Implementation Plans; Partial Approval and Partial Disapproval of Air Quality Implementation Plans and Federal Implementation Plan; Utah; Revisions to Regional Haze State Implementation Plan; Federal Implementation Plan for Regional Haze, 81 Fed. Reg. 2004 (Jan. 14, 2016).

${ }^{69}$ Utah Department of Environmental Quality, EPA's Decision on Utah's Regional Haze SIP (no date)
} 
amounts, depending on the pollutant and the nonattainment classification. ${ }^{70}$ For existing major sources, NSR requirements are applicable to a major modification. For a modification to be major three criteria must be met: (1) a physical change in or change in the method of operation; (2) the change must be at or above the significance levels found in 40 C.F.R. part 51, Appendix S; and (3) the increase in emissions must result in a significant net emissions increase at or above the significance levels. ${ }^{71}$

New or modified major sources must meet the NSR requirements, which include the use of the Lowest Achievable Emission Rate (LAER) control technology. ${ }^{72}$ LAER is based on the most stringent emission limitation in the implementation plan of any state or achieved in practice for the source category under review. ${ }^{73}$ Sources subject to NSR must also offset emissions increases by obtaining emissions reductions from other sources in the area or in an area of equal or higher nonattainment classification that contribute to nonattainment in the proposed major source's area. ${ }^{74}$ The ratio of the offset relative to the proposed increase must be at least one-to-one and is based on the severity of the area's nonattainment classification. Emissions reductions used as offsets must not otherwise be required by the Act, and they must be quantifiable, federally enforceable, and permanent. ${ }^{75}$

In 2011 the EPA issued regulations governing the review of new sources, modifications to existing sources, and minor sources in Indian Country. ${ }^{76}$ The regulations provide a mechanism for permitting major sources in nonattainment areas in Indian country. ${ }^{77}$ Because Tribes generally don't have existing sources from which to generate offsets required for NSR permits, the EPA proposed two options for Tribes to address the lack of available offsets: (1) The Economic Development Zone (EDZ) option, and (2) the Appendix S, paragraph VI option. ${ }^{78}$

The EDZ option is based on section 173(a)(1)(B) of the Act under which the Administrator, in consultation with the Secretary of Housing and Urban Development (HUD), may identify zones within nonattainment areas as EDZs. This would allow major NSR sources located in Indian country to be exempt from the offset requirement in section 173(a)(1)(A) of the Act. In an EDZ area major sources that construct or modify within the EDZ are relieved of the offset requirement if the state or tribe can demonstrate that the new permitted emissions are consistent with the achievement of reasonable further progress pursuant to section 172(c)(4) of the Act and will not

\footnotetext{
${ }^{70}$ CAA $\S 169(1), 42$ U.S.C. $§ 7479(1)$. For greenhouse gases, see 75 Fed. Reg. 31,514.

7176 Fed. Reg. $37,748,38,751$ (July 1, 2011).

7240 C.F.R. $\S \S 49.166-49.175(2015)$. These requirements may be modified in a TIP applicable to a specific area in Indian country. 76 Fed. Reg. at 38,753.

${ }^{73} 40$ C.F.R. § 51.165(a)(1)(xiii).

${ }^{74} 42$ U.S.C. $\S 7503$ (c) (2012).

${ }^{75} \mathrm{CAA} \S 173$ (a) \& (c), 42 U.S.C. $\$ 7503$ (a) \& (c); see also 40 C.F.R. 51.165(a)(3).

${ }^{76} 76$ Fed. Reg. at 38,748 (codified at 49 C.F.R. $\S \S 49.151-49.161$ and 49.166-49.173, and Part 51, Appendix S).

${ }^{77} 40$ C.F.R. § 49.166.

${ }^{78} 76$ Fed. Reg. at 38,773.
} 
interfere with attainment of the applicable NAAQS by the applicable attainment date. The EPA is to consult with HUD, but the Agencies plan to develop approval criteria so that a consultation with HUD is not required every time a Tribe applies for an area of Indian country to be designated as an EDZ. The EPA intends to provide assistance as needed for a Tribe to complete an EDZ designation request. The EPA created a statewide compliance certification requirement that is consistent with section 173(a)(3) of the Act. $^{79}$

A NSR permit applicant must also conduct an analysis of alternative sites, sizes, production processes and environmental control techniques demonstrating that the benefits of the proposed emissions source significantly outweigh the environmental and social costs of its location, construction or modification. ${ }^{80}$ In addition, applicants must demonstrate that all other major sources under its control in the same state are in compliance or on a schedule of compliance with all emission limitations and standards of the Act. 81

The EPA has designated only a few Indian reservations as nonattainment areas. Two Indian lands in California are nonattainment: the Morongo Band of Mission Indians (serious for the 8-hr ozone standard) and the Pechange Band of Luiseno Mission Indians (moderate for the 8-hr. ozone standard). The Fort Hall Indian reservation in Idaho is designated as moderate for $\mathrm{PM}_{10}{ }^{82}$ The Shoshone-Bannock Tribe had the world's largest elemental phosphorous processing plant within its Fort Hall Reservation near Pocatello, Idaho. The reservation was designated nonattainment for $\mathrm{PM}_{10}$, but the facility closed at the end of 2001.83

A much larger number of reservations are located within nonattainment areas designated by states. For example, in San Diego County, California there are twenty reservations for four tribal groups that comprise 193 square miles of the 4205 square miles of the county. ${ }^{84}$ The EPA listed the following tribes as being in nonattainment areas as of April 2012.

\section{Ground Level Ozone: 2008 Standards $^{85}$}

Tribes Designated Nonattainment along with Surrounding State Areas: 49 Tribes

- California-43

\footnotetext{
${ }^{79} 40$ C.F.R. $\S 49.169(\mathrm{~b})(2)$.

${ }^{80} 42$ U.S.C. $\S 7503(5) ; 40$ C.F.R. $\S 49.169(b)(5)$.

${ }^{81} 42$ U.S.C. $\S 7503(\mathrm{a})(3)$.

${ }^{82}$ U.S. Envtl. Protection Agency, Current Nonattainment Counties for All Criteria Pollutants (Jan. 30. 2015).

${ }^{83}$ U.S. EnVtl. Protection Agency, Plan to Address Pollution At Former FMC PhOSPHORUS Processing PLANT 2 (2012), http://www3.epa.gov/region10/pdf/sites/emichaud/IRODA-factsheet-oct2012.pdf .

${ }^{84}$ Vanessa Baehr-Jones \& Christina Cheung, An Exercise of Sovereignty: Attaining Attainment for Indian Tribes Under the Clean Air Act, 34 U. CAL. DAVIS 189, 220 (2011). The tribal groups are the Kumeyaay/Diegueno, the Luiseno, the Cupeno, and the Cahuilla.

${ }^{85}$ Area Designations for 2008 Ground-Level Ozone Standards, EPA (Apr. 2012), http://www3.epa.gov/ozonedesignations/2008standards/final/tribalf.htm.
} 
- Arizona-2

- New York-1

- Connecticut-2

- Massachusetts-1

Tribes Designated Nonattainment Separate from the Surrounding State Nonattainment Area: 2 Tribes

- California-2

Tribes with some Indian Country Designated Nonattainment along with the Surrounding State Area: 2 Tribes

- California-1

- Arizona-1

Tribes Designated Unclassifiable/Attainment Separate from Surrounding State Nonattainment Area: 1 Tribe

- South Carolina-1

Tribes Designated Unclassifiable Attainment Separate from Surrounding Unclassifiable/Attainment Area: 1 Tribe

- Colorado-1

\section{Nitrogen Dioxide: 2010 Standards $^{86}$}

All tribes listed unclassifiable/attainment.

\section{Sulfur Dioxide: 2010 Standards ${ }^{87}$}

- Fond du Lac Band of Lake Superior Chippewa-No violations so no nonattainment designation

- Forest County Potawatomi Community-No violations so no nonattainment designation

- Pechanga Band of Luiseno Mission Indians - No violations so no nonattainment designation

- San Carlos Apache Tribe-Violations at 2 nearby monitoring stations but not indicative of sulfur dioxide levels on the reservation; therefore, there was no nonattainment designation

- Southern Ute Indian Tribe-No violations so no attainment designation

\section{Lead: 2008 Standards $^{88}$}

\footnotetext{
${ }^{86}$ Nitrogen Dioxide Designations, EPA (2010), http://www3.epa.gov/no2designations/tribal.html.

${ }^{87}$ Sulfur Dioxide Designations, EPA, http://www3.epa.gov/airquality/sulfurdioxide/designations/tribal.html (last visited Feb. 19, 2016). This website includes a link to letters from the tribe to the EPA regarding sulfur dioxide designations, and EPA's response to the tribe.
} 
No tribe is listed as nonattainment.

\section{PM2.5: 2012 Standard $^{89}$}

2014 EPA Designations

- 12 Nonattainment (all in California)

- 20 unclassifiable/attainment

\section{2006 24-Hour PM 2.5 Standards ${ }^{90}$}

2009 EPA Designations: 22 Tribes in Nonattainment Areas

- Wisconsin-1

- Washington-1

- California-20

\section{§ 2(E). EPA's Operating Permit Program}

The 1990 CAA Amendments created Title V, which for the first time mandated a comprehensive operating permit program to regulate air emissions from major stationary sources. ${ }^{91}$ Minor sources are commonly subject to state permit programs, and the EPA has promulgated a minor source program for emission sources in Indian country. ${ }^{92}$ In addition, the operating permit program identifies the existing SIP program's requirements applicable to specific sources as well as requirements imposed by other provisions of the CAA. The operating permit program, which is primarily implemented by the states, attempts to place the CAA "applicable requirements" in one document. ${ }^{93}$

The EPA issues operating permits under Subchapter V only if a state either does not establish an operating permit program that meets EPA's requirements found at 40 C.F.R. Part 70 or does not accept delegation of EPA's permitting authority as provided by 40 C.F.R. $\S$ 71.10. However, the EPA is responsible for administering the operating permit program in Indian country although this responsibility may be delegated. The operating permit program must, at a minimum, contain the elements required by CAA section 502(b). ${ }^{94}$ They include:

\footnotetext{
${ }^{88}$ Area Designations for 2008 Lead Standards, EPA (2008), http://www3.epa.gov/leaddesignations/2008standards/tribal.html.

${ }^{89}$ Area Designations for the 2012 Annual Final Particle (PM 2.5$)$ Standard, EPA (2012),

http://www3.epa.gov/pmdesignations/2012standards/index.htm; Tribal Recommendations and EPA

Responses for Area Designations, in Area Designations for the 2012 Annual Final Particle (PM 2.5$)$ Standard, EPA (2012), http://www3.epa.gov/pmdesignations/2012standards/tribalrec.htm.

${ }^{90}$ Area Designations for 2006 24-Hour PM 2.5 Standards-Final Tribal Designations, EPA (Oct. 2009), http://www3.epa.gov/pmdesignations/2006standards/tribal.htm.

${ }^{91}$ CAA $\S \S 501-507,42$ U.S.C. $\S \S 7661-7661 \mathrm{f}$.

92 The Indian country minor source program is discussed infra $\S 2(\mathrm{~F})$.

93 Sierra Club v. Ga. Power Co., 443 F.3d 1346 (11th. Cir. 2006).

${ }^{94} 42$ U.S.C. $§ 7661$ a.
} 
1) requirements for permit applications, including standard application forms and criteria for determining the completeness of applications;

2) monitoring and reporting requirements;

3) a permit fee system to finance the air pollution control program;

4) provisions for adequate personnel and funding to administer the program;

5) authority to issue permits and assure that each permitted source complies with applicable requirements under the Act; ${ }^{95}$

Under CAA $\S 502(a)$, the following sources must obtain an operating permit: affected sources as provided in Subchapter IV's acid rain program; facilities that emit, or have the potential to emit, 10 TPY or more of any HAP or 25 TPY of any combination of HAPs (CAA $\S 112$ ); sources required to have an NSR permit because they are major as defined by Part D of Subchapter 1; any source emitting 100/250 TPY required to have a preconstruction review permit by Part C of Subchapter I (PSD); other major sources, as defined in CAA $\S 302$ that are located in nonattainment areas and that have emissions of 100 TPY or more of any regulated pollutant; any other source, including an area source, that is subject to a CAA $\S 112$ HAP standard or a CAA $\S 111$ New Source Performance Standard (NSPS); and any other stationary source in a category designated by regulations promulgated by the Administrator.

Determining which sources are major is affected by the rules developed under CAA $\S$ 111 for NSPS. Major stationary sources located on contiguous or adjacent properties, under common control, and belonging to a single two-digit Standard Industrial Classification (SIC) have their emissions combined to determine whether emissions exceed the threshold level. ${ }^{96}$ Sources of HAPs are major based on the aggregate emissions of a stationary source or group of stationary sources within a contiguous area and under common control without reference to the SIC of the source. ${ }^{97}$ Fugitive emissions are used to determine whether a source is major if the source is one of twenty-six categories listed in the regulation.

Applicants for permits must submit the permit application that meets the requirements of CAA $\S 504$ and 40 C.F.R. $\S \S 70.5(\mathrm{a})(2) \& 70.6$. Each permit application must include at a minimum: (1) a description of the facility's processes and products; (2) a list of all air emissions from the facility; (3) emission rates in tons per year; (4) information on fuels, fuel use, raw materials, production rates, and operating schedules; and (5) a description of air pollution control equipment. ${ }^{98}$ The permit application must include a certification by a responsible official attesting to the truth and accuracy of the permit application. ${ }^{99}$ Applicants may avoid a "major source" classification by accepting emission limits in an operating permit below the tons per year major source threshold or by accepting operational limits that have a similar effect. ${ }^{100}$

\footnotetext{
${ }^{95}$ CAA $\S 502(\mathrm{~b})(6)-(10)$ imposes other requirements on a permit program.

${ }^{96} 40$ C.F.R. $\$ 70.2$ (2015).

${ }^{97} 40$ C.F.R. $\$ 63.2$.

9840 C.F.R. $\$ 70.5(\mathrm{c})$.

${ }^{99} 40$ C.F.R. $\$ 70.5(d)$.

${ }^{100}$ See infra $\S 1(\mathrm{~F})$.
} 
A compliance plan is also required, which includes a schedule for compliance (defined at CAA § 501(3)). ${ }^{101}$ A compliance schedule must include a schedule of remedial measures to be taken and must be submitted within twelve months of the date on which the source becomes subject to a permit program. It must include a description of how the facility will achieve compliance with requirements for which the facility is not currently in compliance. ${ }^{102}$ A responsible official must sign the application as well as the compliance plan, compliance schedule, annual compliance certification, and all reports that are required to be submitted to the permitting authority. The responsible official's signature certifies, under penalty of law, that the statements and information in the documents are true, accurate, and complete. ${ }^{103}$

Section 505(b), provides for states (or tribes) to develop and run an operating permit program, but EPA may veto the issuance of permits. Regulations concerning the process for permit issuance, review, renewal, revision, and reopening are found at 40 C.F.R. $\S \S 70.7$ and 70.8. Under the regulations the permitting authority must submit to EPA any application for a permit, renewal, or revision, including any compliance plan. ${ }^{104}$ The permitting authority also is required to notify all affected states of each item that must be forwarded to EPA. Affected states are those whose air quality may be affected or are contiguous to the state in which the source is located or are within fifty miles of the source. ${ }^{105}$ The permitting authority must accept written recommendations from affected states; if they are rejected, it must explain the reasons in writing. ${ }^{106}$

If new requirements are imposed under the CAA, the permitting authority is required to revise all major source permits subject to the new requirements that have a remaining life of three or more years. However, no permit revision is necessary if the effective date of the requirement is after the expiration of the permit. The permitting authority must have the right to terminate, modify, or revoke permits for cause. Reopenings for cause are subject to the requirements of CAA $\S 505(\mathrm{e})$ and the applicable regulations title. ${ }^{107}$

In 2011 no Tribe had an EPA-approved Title $V$ permitting program or had adopted any other program to implement section $112(\mathrm{~g})$. In 2012, the EPA approved the Title V Operating Permit for Colorado's Southern Ute Tribe. ${ }^{108}$ However, the Navajo Nation had been delegated authority to assist with implementation of the Federal part 71 operating permit program. ${ }^{109}$ The EPA has issued 46 Title $\mathrm{V}$ permits to major sources located on Indian tribe lands in its Region 2, 5, 6, 8, 9 \& 10. Seventeen of the permits are for

\footnotetext{
${ }^{101}$ CAA $\S 503(b), 42$ U.S.C. $\S 7661 b(b)$.

10240 C.F.R. $\$ 70.5(\mathrm{c})$.

10340 C.F.R. \& 70.6(c)(9).

10440 C.F.R. $\$ 70.8(\mathrm{a})$.

${ }^{105} 40$ C.F.R. $\$ 70.2$.

${ }^{106} 40$ C.F.R. $\S 70.8(b)$.

10740 C.F.R. $§ 70.7(f)$.

${ }^{108}$ U.S. Envtl. Protection Agency, Clean Air Act Full Approval of Title V Operating Permits Program; Southern Ute Indian Tribe, 77 Fed. Reg. 15,267 (Mar. 15, 2012).

${ }^{109}$ Navajo Nation Envtl. Protection Agency, Title V Permit to Operate.
} 
facilities in Region 8 covering New Mexico, Wyoming, Colorado, Montana, Utah, and North Dakota. There are no permits in EPA Region 1, 3, 4, \& 7.110

\section{§ 2(F). Minor Source Permit Programs}

A permitting program for minor sources is to be developed by the states based on federal requirements. ${ }^{111}$ Most minor sources located in Indian country, however have not been regulated, and only a few Tribes administer EPA-approved minor NSR programs. ${ }^{112}$

On July 1, 2011, the EPA promulgated an Indian country FIP that applies to new and modified minor stationary sources and minor modifications at existing major stationary sources. ${ }^{113}$ The FIP also provides for a case-by-case determination of the MACT for sources of HAPs. ${ }^{114}$

On May 1, 2015, an additional regulation for the minor source program in Indian country was promulgated. ${ }^{115} \mathrm{~A}$ minor source is a source, not including the exempt emissions units and activities listed in 40 C.F.R. $\S 49.153$ (c), with the potential to emit regulated NSR pollutants below the major source thresholds, but above minor NSR thresholds. ${ }^{116}$ Beginning September 2, 2014, any new stationary source that has the potential to emit (PTE) a regulated NSR pollutant in amounts equal to or greater than the minor NSR thresholds must apply for and obtain a minor NSR permit before commencing construction. A source's PTE for a pollutant is expressed in tons per year (tpy) and calculated by multiplying the maximum hourly emissions rate in pounds per hour (lbs/hr) times 8,760 hours (the number of hours in a year) divided by 2,000 (the number of pounds in a ton). If a source's emissions are restricted by enforceable permit conditions that limit its PTE, the allowable emissions are calculated based on the permit

\footnotetext{
${ }^{110}$ Region 1: http://www.epa.gov/caa-permitting/epa-issued-caa-permits-region-1

Region 2: http://www.epa.gov/caa-permitting/caa-permits-issued-epa-region-2\#part71permits

Region 3: http://www.epa.gov/caa-permitting/caa-permitting-epas-mid-atlantic-region

Region 4: http://www.epa.gov/caa-permitting/caa-permitting-epas-southeastern-region

Region 5: http://yosemite.epa.gov/r5/r5ard.nsf/Tribal+Permits\%210penView

Region 6: http://www.epa.gov/caa-permitting/part-71-operating-permits-tribal-lands-epas-south-central-region

Region 7: http://www.epa.gov/caa-permitting/status-tribal-air-permits-region-7

Region 8: http://www.epa.gov/caa-permitting/caa-permits-issued-epa-region-8

Region 9: http://www.epa.gov/caa-permitting/title-v-permits-issued-region-9

Region 10: http://www.epa.gov/caa-permitting/air-permits-issued-epa-region-10

111 See 40 C.F.R. $\S \S 51.160-164$.

112 U.S. Envtl. Protection Agency, Review of New Sources and Modifications in Indian Country, 76 Fed. Reg. 38,748, 38,755 (July 1, 2011).

${ }^{113} I d$. The minor source program is codified at 40 C.F.R. $\S \S 49.151-49.165$.

${ }^{114} \mathrm{Id}$.

${ }^{115}$ U.S. Envtl. Protection Agency, General Permits and Permit by Rule for the Federal Minor New Source Review Program in Indian Country for Five Source Categories, 80 Fed. Reg. 25,068 (May 1, 2015).

${ }^{116}$ Major source thresholds are found at 40 C.F.R. $\S \S 49.167 \& 52.21$ (PSD). Nonattainment major thresholds are found at 40 C.F.R. $\S \S 49.166-49.173$. Minor thresholds are found at 40 C.F.R. $\S 49.153$.
} 
restrictions. ${ }^{117}$

A proposed modification of an existing major source that does not qualify as a major modification is subject to the minor NSR program requirements if the net emissions increase from the actual-to-projected-actual test is equal to or above the minor NSR thresholds listed in Table 1 of the rule. However, the emissions must be less than the amount that would qualify the source as a major source or a major modification for purposes of the more stringent PSD or nonattainment NSR programs. ${ }^{118}$ The minor thresholds are much lower than the significance level and are more stringent for nonattainment areas than for attainment areas. ${ }^{119}$

Fugitive emissions are included to the extent they are quantifiable for source categories listed in the regulations. ${ }^{120}$ These sources must install and operate control technology as determined by the reviewing authority on a case-by-case basis. These sources may also be required to submit air quality impact analyses as part of their permit applications. As an alternative to a site-specific permit, minor sources can request coverage under a general permit. ${ }^{121}$ Moreover, the EPA has developed a list of activities that are exempted from the minor NSR program. ${ }^{122}$ The list was expanded on May 30, 2014.123

The EPA estimates that about one percent (or less) of total emissions will be exempt from review under the minor NSR program, while the thresholds will exempt 42 percent to 76 percent of sources (depending on the pollutant) from preconstruction review due to the minor source thresholds. ${ }^{124}$

\footnotetext{
11776 Fed. Reg. at $38,755$.

11880 Fed. Reg. at 25,070.

${ }^{119} I d$.

${ }^{120} 76$ Fed. Reg. at 38,754 . The categories are found at 40 C.F.R. pt. 51, App. S and 40 C.F.R. $\S 52.21(b)(1)(i i i)$.

${ }^{121} \mathrm{Id}$. at 38,750 .

${ }^{122} I d$.

${ }^{123}$ U.S. Envtl. Protection Agency, Review of New Sources and Modifications in Indian Country-Amendments to the Federal Indian Country Minor Source Review Rule, 79 Fed. Reg. 31,035 (May 30, 2014).

${ }^{124} 76$ Fed. Reg. at $38,758$.
} 
The Indian Country Minor NSR rule incorporates by reference six federal rules. They are: 1) National Emission Standards for Hazardous Air Pollutants for Major Sources: Industrial, Commercial, and Institutional Boilers and Process Heaters; ${ }^{125}$ 2) Standards of Performance for Volatile Organic Liquid Storage Vessels (Including Petroleum Liquid Storage Vessels) for Which Construction, Reconstruction, or Modification Commenced After July 23, 1984;126 3) Standards of Performance for Stationary Compression Ignition Internal Combustion Engines; ${ }^{127} 4$ ) Standards of Performance for Stationary Spark Ignition Internal Combustion Engines; ${ }^{128}$ 5) Standards for New and Modified Sources in the Oil and Natural Gas Sector; ${ }^{129}$ and 6) National Emission Standards for Hazardous Air Pollutants from Oil and Natural Gas Production Facilities. ${ }^{130}$ There are numerous other amendments to the Indian Country Minor NSR Rule.131 The proposed FIP is needed because in September 2015 there were no approved TIPs covering areas subject to the Federal Indian Country Minor NSR rule. ${ }^{132}$

States that have a federally enforceable minor source permit program may designate sources that have the potential to emit above the major source thresholds as "synthetic minor" minor sources if they accept enforceable permit limits on emissions that keep the emissions below the major source threshold. ${ }^{133}$ However, this program was not available in Indian country until July 1, 2011. EPA does allow sources located in Indian country to avoid major source requirements if they demonstrate the actual emissions from the source are continuously less than half the major source threshold over a 12-month period. ${ }^{134}$

The 2011 rule established the first synthetic minor source permitting mechanism for major sources of regulated NSR pollutants and/or HAPs in Indian country. A synthetic minor source permit is available under the PSD, nonattainment major NSR and Title $\mathrm{V}$ programs as well as by synthetic minor sources for MACT standards and Title $V$ purposes. HAP sources having synthetic minor permits must comply with emissions limits that are enforceable as a practical matter and with the applicable regulations found in 40 CFR part $63.135 \mathrm{~A}$ synthetic minor source for NSR that has other applicable requirements that make it major for Title $V$ purposes, must also apply for a part 71 , Title $V$ permit. ${ }^{136}$

To obtain a synthetic source designation requires the source to agree to limit

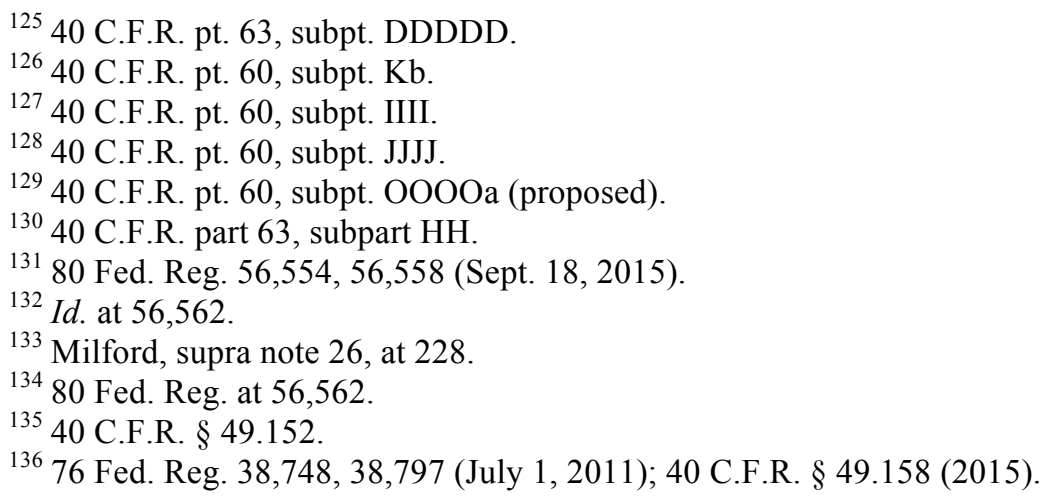


emissions below the major source trigger. ${ }^{137}$ The agreement to limit emissions must be enforceable as described in 40 C.F.R. $\S 49.152$. This rule is implemented by the EPA or by a delegated tribal agency. Synthetic minor sources need a sitespecific permit, but EPA is developing general permits, discussed below at $\S 1(G)$, for some common types of minor sources in order to streamline the permitting process. ${ }^{138} \mathrm{An}$ applicant for a synthetic minor designation must also comply with minor source regulations concerning public participation requirements, the procedures for final permit issuance and administrative and judicial review. ${ }^{139}$

On June 3, 2016, the EPA promulgated a FIP applicable to the oil and gas industry that is to be used to regulate most minor sources rather than using sourcespecific minor source preconstruction permits. This is discussed in $\S 4(\mathrm{C})$ infra.

\section{§ 2(G). General Permits}

A "general permit" is a preconstruction permit used to regulate numerous similar emissions from new or modified true minor sources in a cost-effective manner for both the government and the source. They streamline the preconstruction permitting through the issuance of one permit that can apply to multiple stationary sources that have similar emissions. The EPA finalized the general permit issuance process at 40 C.F.R. $\S 49.156$ (b) in July 2011 as part of the Federal Indian Country Minor NSR rule. ${ }^{140}$ The reviewing authority may issue a general permit for a category of emissions units or sources that are similar, have substantially similar emissions, and would be subject to the same or substantially similar requirements governing operations, emissions, monitoring, reporting and recordkeeping. ${ }^{141}$

A general permit when issued is considered final action with respect to all aspects of the permit except its applicability to an individual source. The sole issue that may be appealed after a permit approval is the applicability of the general permit to a particular source. ${ }^{142}$ The reviewing authority determines which categories of individual emissions units, groups of similar emissions units, or sources are appropriate for general permits in its geographic area. ${ }^{143}$

Emissions units covered by a general permit should usually have similar operations or processes and emit pollutants with similar characteristics. They should be able to handle the same or substantially similar permit requirements

${ }^{137}$ Id. at 38,749 .

${ }^{138} \mathrm{Id}$.

13940 C.F.R. $\S \S 49.157,49.159$.

14076 Fed. Reg. at 38,748 .

${ }^{141} \mathrm{Id}$. at 38,767 .

${ }^{142} \mathrm{Id}$.

${ }^{143} I d$. 
governing operation, emissions, monitoring, recordkeeping, and reporting. ${ }^{144}$ The EPA is in the process of developing general permits for various source categories under the factors mentioned. General permits must deal with the same permit elements required for permits issued under the site-specific preconstruction review rules. These permit elements are described in 40 C.F.R. $§ \quad 49.155$. However, the EPA will not allow general permits to be issued for synthetic minor sources. ${ }^{145}$

On May 1, 2015, the EPA finalized a rule concerning general permits in Indian country for new or modified minor sources in two source categories: Hot mix asphalt (HMA) plants; and stone quarrying, crushing, and screening (SQCS) facilities. ${ }^{146}$ The EPA also authorized the use of general permits to create synthetic minor sources for the HMA and SQCS source categories. ${ }^{147}$ The Agency finalized permits by rule for new or modified minor sources in three source categories: auto body repair and miscellaneous surface coating operations; gasoline dispensing facilities (GDFs), except in California; and petroleum dry cleaning facilities. ${ }^{148}$ Permits by rule requirements are codified in the Code of Federal Regulations and they pre-authorize construction and modification activities that are carried out in accordance with the codified requirements. The EPA is expected to release a rule to specifically manage oil and gas emissions from minor sources on Indian lands in March 2016. ${ }^{149}$

To become covered by a permit a source must notify the reviewing authority that it meets the terms of coverage and is complying with the permit's terms and conditions but does not need the approvals required for a source specific permit. The source must also submit a Notification of Coverage Form in fulfillment of the minor source registration requirement in the Federal Indian Country Minor NSR rule. Once it has done so and the reviewing authority has posted the Notification of Coverage Form online, the source may commence construction of a new source or modification of an existing source. ${ }^{150}$ The regulations do not allow the use of permits by rule to create synthetic minor sources. ${ }^{151}$

\section{$\S$ 3. Tribal Regulation of Air Quality}

\footnotetext{
${ }^{144}$ Id. at 38,768 .

${ }^{145} \mathrm{Id}$. at 38,770 .

${ }^{146}$ U.S. Envtl. Protection Agency, General Permits and Permits by Rule for the Federal Minor New Source Review Program in Indian Country for Five Source Categories, 80 Fed. Reg. 25,068 (May 1, 2015).

${ }^{147} I d$. at 25,070 .

${ }^{148} I d$. at 25,068 .

${ }^{149}$ Patrick Ambrosio, Petroleum Industry Seeks Stay in Litigation Over EPA Rule for Permitting on Tribal Lands, 46 ENV'T REP. (BNA) 2328 (Aug. 7, 2015).

${ }^{150} 80$ Fed. Reg. at 25,069.

${ }^{151} \mathrm{Id}$. at 25,070 .
} 
The efforts by Indian tribes to use the CAA to advance tribal interests became more focused when the 1977 CAA Amendments authorized federally recognized tribes to redesignate land within the exterior boundaries of their reservations under the Act's PSD program. ${ }^{152}$ This program classified areas that met the NAAQS into three classes with the least air quality deterioration allowed in Class I, and the most deterioration allowed in Class III areas providing the NAAQS were not exceeded. ${ }^{153}$

By changing the status of a reservation to Class I a tribe can make it difficult or even impossible for major emitting sources constructed after August 7, 1977, to locate either inside the reservation's boundary or outside the boundary if the air quality of the Class I area is projected to be impacted above the legally allowed increase, known as the increment. 154 Moreover, even if the allowed atmospheric concentration of a regulated pollutant does not exceed the increment, a permit for a new source or major modification of an existing source can be denied if it will violate "air quality related values," including visibility. 155 However, visibility protection only applies to mandatory Class I areas (e.g. national parks and wilderness areas). Non-mandatory Class I areas are only covered if they are part of the statutory dispute resolution process. ${ }^{156}$ If there is a dispute among tribes concerning classification, a mechanism is provided to allow the EPA to resolve disputes between states and tribes. ${ }^{157}$ This ability to redesignate areas allowed Indian tribes to influence development within the exterior boundaries of their reservations as well as development upwind of reservations.

In 1977 the Northern Cheyenne Tribe requested Class I status for its reservation based on the EPA's 1974 PSD regulation. ${ }^{158}$ On August 5, 1977 the redesignation was approved days before the PSD program, including the right for tribes to redesignate tribal lands, was codified by the 1977 CAA Amendments. ${ }^{159}$ Thus, the Northern Cheyenne Tribe was first tribe to utilize the redesignation process. ${ }^{160}$ In 1981, the Ninth Circuit upheld the EPA's delegation to Indian tribes the authority to redesignate their lands. ${ }^{161}$ This redesignation resulted in the Montana Power Company being blocked from completing two new coal strip units. ${ }^{162}$ The units were eventually constructed after they agreed to install wet scrubbers to meet the Tribes PSD increment for sulfur dioxide. ${ }^{163}$ The

${ }^{152}$ CAA § 164(c), 42 U.S.C. § 7474(d).

${ }^{153}$ CAA $\S 162,42$ U.S.C. $\S 74702$.

${ }^{154}$ CAA $\S \S 161-165,42$ U.S.C. $\$ \S 7471-7475$.

${ }^{155}$ CAA $165(\mathrm{~d})(2)(\mathrm{C})(\mathrm{ii}), 42$ U.S.C. $\$ 7475(\mathrm{~d})(2)(\mathrm{C})(\mathrm{ii})$.

${ }^{156}$ CAA $\S 164(\mathrm{e}), 42$ U.S.C. 7474(e).

${ }^{157}$ CAA $\$ 164(\mathrm{e}), 42$ U.S.C. $\S 7474(\mathrm{e})$.

${ }^{158} 42$ Fed. Reg. 21,819 (Apr. 29, 1977).

${ }^{159}$ CAA $\S 164(\mathrm{c}), 42$ U.S.C. $\S 7474(\mathrm{c})$.

${ }^{160} 42$ Fed. Reg. 40,695 (1977).

${ }^{161}$ Nance v. EPA, 645 F.2d 701 (9th Cir. 1981).

162 See Montana Power Co. v. EPA, 608 F.2d 334, 343 (9th Cir. 1979).

${ }^{163}$ Baehr-Jones \& Cheung, supra note 81, at 213. 
redesignation was opposed by the Crow Indian Tribe, which wanted the electric power project to be constructed. ${ }^{164}$

In 1984 the EPA issued a policy statement saying that until tribal governments are able to assume full responsibility for administering delegable programs, the Agency will retain responsibility for managing the environmental programs, but will encourage tribal participation. ${ }^{165}$ For a non-compliant facility that is tribally owned the EPA will work cooperatively with the tribe to achieve compliance, but if the facility is owned or managed by private parties the Agency will deal with environmental violations in the same way it would respond if Indian land was not involved. ${ }^{166}$ The 1984 policy was updated in $2011 .{ }^{167}$

In 1982 the EPA approved the Confederated Salish and Kootenai Tribe's Flathead Reservation in northwest Montana being redesignated to Class I. ${ }^{168}$ The EPA approved the redesignation of the Fort Peck reservation to Class I in 1984,169 which resulted in the Sioux and Assiniboine tribes preventing a coal-fired electric power facility from being constructed. ${ }^{170}$ In 1991 the EPA approved the Spokane Reservation in Washington being redesignated as Class I.171 On November 1, 1996, the EPA approved the redesignation of the Yavapai-Apache Reservation in Arizona to Class I. ${ }^{172}$ In 2008, the EPA approved the redesignation of the Forest County Potawatomi Community Reservation in Wisconsin to Class I. ${ }^{173}$ Nearly all redesignations involve the effort of tribes to prevent industrial development outside the boundaries of the reservation. However, once redesignation occurs, the tribe also has the limits imposed on its emissions producing development. In 2013 the EPA issued guidance for Indian tribes seeking redesignation of lands within their exterior borders to Class I. ${ }^{174}$

\section{§ 3(A). Tribes As States}

\footnotetext{
${ }^{164}$ Nance, 645 F.2d at 714.

${ }^{165}$ EPA POLICY FOR THE ADMINISTRATION OF ENVIRONMENTAL PROGRAMS ON INDIAN RESERVATIONS (Nov. 8. 1984) [hereinafter 1984 EPA POLICY], http://www3.epa.gov/air/tribal/WETG/wetg2014/indianpolicy_1984.pdf.

${ }^{166}$ Id. at 4.

${ }^{167}$ EPA POLICY ON CONSULTATION AND COORDINATION WITH INDIAN TRIBES, supra note 39.

16847 Fed. Reg. 23,927 (1982).

16949 Fed. Reg. 4734 (1984).

${ }^{170}$ Baehr-Jones \& Cheung, supra note 81.

${ }^{171}$ U.S. Envtl. Protection Agency, Approval and Promulgation of State Implementation Plans, 56 Fed. Reg. 14,861 (Apr. 12, 1991); 40 C.F.R. § 52.2497(c).

17261 Fed. Reg. 56,461(1996); 40 C.F.R. $§ 52.150(a),(b)$.

17373 Fed. Reg. 23,806 (May 29, 2008).

174 GUIDANCE FOR INDIAN TRIBES SEEKING ClASS I REDESIGNATION OF INDIAN COUNTRY PURSUANT TO SECTION 164(C) OF THE CleAn Air ACT (Aug. 29, 2013), http://www3.epa.gov/air/tribal/pdfs/GuidanceTribesClassIRedesignationCAA.pdf.
} 
The EPA administers the implementation of the CAA within Indian country until a tribal program is approved. ${ }^{175}$ In 1984 EPA adopted an Indian Policy that recognized the importance of close involvement by the EPA with tribal governments in making decisions and managing environmental programs affecting Indian tribes. ${ }^{176}$ In the 1990 CAA Amendments Congress expanded the power of Indian tribes to control air pollution by providing a path for Indian tribes to be treated as states (TAS), which allows tribes to administer and enforce the CAA in Indian lands. ${ }^{177}$ It also added a provision that provides an intergovernmental dispute resolution mechanism between the states and tribes. ${ }^{178}$

The ability of Indian tribes to protect the environment was expanded in 1986 by the Safe Drinking Water Act (SDWA), 179 the Clean Water Act (CWA) in 1987, 180 and the Surface Mining Control and Reclamation Act (SMCRA) in 1977. ${ }^{181}$ The Resource Conservation and Recovery Act (RCRA) is the major statute administered by the EPA that does not have a TAS provision. ${ }^{182}$ Under RCRA Indian tribes are treated as municipalities. ${ }^{183}$ However, the states are prohibited from using RCRA as a basis for jurisdiction in Indian country. ${ }^{184}$ The Comprehensive Environmental Response, Compensation, and Liability Act (CERCLA) in section 26 that was added in 1986, provides for tribes to be treated as states for specific provisions of the statute including notification of releases consultation concerning remedial action affecting a tribe, but it does not recognize tribal authority to the same extent as the other pollution control statutes. ${ }^{185}$

The 1990 CAA Amendments expanded the power of Indian tribes to control air pollution in Indian country by providing a path for Indian tribes to be treated as states (TAS). ${ }^{186}$ The Amendments provide Indian tribes with opportunities for air pollution program planning, implementation, and enforcement. CAA $\S 105$ can be used to obtain funds to implement tribal air pollution programs. ${ }^{187}$ TAS status allows tribes to petition EPA under CAA $\S 126$

\footnotetext{
${ }^{175} 64$ Fed. Reg. 8247, 8249 (Feb. 19. 1999).

1761984 EPA POLICY, supra note 165; see David F. Coursen, Tribes as States: Indian Tribal Authority to Regulate and Enforce Federal Environmental Laws and Regulations, 23 ENVTL. L. REP. (News \& Analysis) 10579 (Oct. 1993).

${ }^{177}$ CAA $\S 301(d), 42$ U.S.C. $\S 7601(d)$. In 1994, EPA adopted a policy that TAS would mean "treatment in a manner similar to a state." 59 Fed. Reg. 64,339 (Dec. 14, 1994).

17842 U.S.C. $\S 7474(\mathrm{e})$ (2012).

${ }^{179}$ SDWA $\S 1451,42$ U.S.C. $\S 300 j-11$.

${ }^{180}$ CWA $\S 518,33$ U.S.C. $\S 1377$.

18130 U.S.C. $\$ 1300(j)$.

18242 U.S.C. $\$ \S 6901-6992(\mathrm{k})$.

${ }^{183} 42$ U.S.C. $\S 6903(13)(A)$.

${ }^{184}$ Wash. Dep't of Ecology v. EPA, 752 F.2d 1465, 1469 (9th Cir. 1985).

18542 U.S.C. $\$ 9626$.

${ }^{186}$ CAA $\S 301(d), 42$ U.S.C. $\S 7601(d)$.

18742 U.S.C. $\S 7405$.
} 
to impose control requirements on upwind sources that significantly contribute to a violation of an air quality standard in a downwind area. ${ }^{188}$

The CAA includes an Indian tribal agency in its definition of an "air pollution control agency." 189 Section 302(r) of the CAA defines an Indian tribe as "any Indian tribe, band, nation, or other organized group or community, including any Alaska Native village, which is Federally recognized as eligible for the special programs and services provided by the United States to Indians because of their status as Indians."190

In 1998 the EPA promulgated its Tribal Authority Rule (TAR), which sets forth the requirements for a tribe to obtain TAS status. ${ }^{191}$ This status allows a tribe to implement the programs of the CAA such as the development of implementation plans, the PSD program, and title $\mathrm{V}$ permitting program. The TAR also sets out the requirements that a tribe must meet to have an approved tribal implementation plan (TIP). The TAR was upheld in Arizona Public Service Co. v. EPA. ${ }^{192}$

The EPA provides guidance concerning the procedural steps that must be followed for a tribe to be given TAS status. ${ }^{193}$ After pre-application discussions and technical assistance a tribe submits an application to the EPA, which reviews the application. The EPA notifies the appropriate governmental entities, identifies the reservation's boundaries and any assertions concerning tribal authority over non-reservation areas, and notifies the tribe when the application is complete. ${ }^{194}$ A public comment period follows, and the tribe is given the opportunity to review the comments and to respond. The EPA produces a draft decision, which includes a response to comments for final review within the Agency. If the application is approved, the regional office notifies the tribe in a letter that includes the boundaries of the reservation and the tribal jurisdiction over non-reservation areas. ${ }^{195}$

As of October 2015 there were forty-nine tribes (some with multiple approvals) that had TAS status for various CAA provisions. ${ }^{196}$ Region 8 has nine tribes with TAS approval: the Arapaho Tribe of the Wind River Reservation,

18842 U.S.C. $\S 7426$.

${ }^{189}$ CAA $\S 302(b)(5), 42$ U.S.C. $\S 7602(b)(5)$.

${ }^{190} 42$ U.S.C. $\$ 7602(r)$.

${ }^{191}$ U.S. Envtl. Protection Agency, Indian Tribes: Air Quality Planning and Management, 63 Fed. Reg. 7254 (Feb. 12, 1998) (codified at 40 C.F.R. pt. 49).

192211 F. 3d 1280, 1288 (D.C. Cir. 2000), cert. den., 532 U.S. 970 (2001).

${ }^{193}$ U.S. Envtl. Protection Agency, Procedural Steps for Processing Tribal Applications for TAS Eligibility for Regulatory Programs Under the Clean Air Act, (no date), <www3.epa.gov/air/tribal/tas_elig.html >. ${ }^{194} \mathrm{Id}$.

${ }^{195} \mathrm{Id}$.

${ }^{196}$ E-mail from Regina Chappell, Liaison, Office of Air Quality Planning \& Standards, U.S. Envtl. Prot. Agency, to Sheena M. Christman, Research Assistant, S.J. Quinney Coll. of Law (Oct. 27, 2015, 1:19 PM) (unpublished spreadsheet) (on file with author). 
Wyoming; Assiniboine and Sioux Tribes of the Fort Peck Reservation, Montana; Blackfeet Tribe of the Blackfeet Indian Reservation of Montana; Confederated Salish and Kootenai Tribes of the Flathead Reservation, Montana; Northern Cheyenne Tribe of the Northern Cheyenne Indian Reservation, Montana; Shoshone Tribe of the Wind River Reservation, Wyoming; Southern Ute Indian Tribe of the Southern Ute Reservation, Colorado; Three Affiliated Tribes of the Fort Berthold Reservation, North Dakota; and the Ute Indian Tribe of the Uintah \& Ouray Reservation, Utah. ${ }^{197}$ Region 9 has ten TAS reservations; and Region 10 has thirteen TAS reservations. ${ }^{198}$ Thus about two-thirds of the TAS reservations are in the West.

TAS status allows tribes to seek primacy to implement the CAA through a TIP or to seek a more limited role by seeking primacy over specific CAA regulatory programs. EPA allows a TAS and primacy applications to be filed together. ${ }^{199}$ Indian tribes must meet specified requirements to be granted TAS status. First, the Indian tribe must have a governing body that has substantial governmental duties and powers. ${ }^{200}$ The EPA expects the tribes to have independent regulatory authority. ${ }^{201}$ Second, the air pollution control functions to be exercised by the Indian tribe must pertain to air resource management and protection within the exterior boundaries of the reservation (including tribal trust lands outside reservation boundaries). ${ }^{202}$ The EPA interprets this requirement to cover sources within the reservation to include non-Indians within the reservation boundaries. ${ }^{203}$ To deal with emissions from outside the reservation boundaries requires the tribe to demonstrate its regulatory authority under general principles of Indian law. ${ }^{204}$ Third, the Indian tribe must be "reasonably capable" of performing the duties and functions associated with the CAA. 205 The term "capable" has both economic and technical ability requirements.

After TAS approval, the EPA continues to remain the sole criminal enforcement authority over non-Indians. ${ }^{206}$ However, the EPA allows tribes to enter into agreements that allow the tribe to work with the Agency to assist in developing criminal enforcement actions. ${ }^{207}$ The TAR also exempts tribes with

\footnotetext{
${ }^{197} I d$.

${ }^{198} I d$.

19959 Fed. Reg. 64,339 (Dec. 14, 1994).

${ }^{200}$ CAA $\S 301(d)(2)(A), 42$ U.S.C. $\S 7601(d)(2)(A)$.

${ }^{201}$ See e.g., 53 Fed. Reg. 37,396, 37,401 (Sept. 26, 1988); 58 Fed. Reg. 67,966, 67,971 (Dec. 22, 1993).

${ }^{202}$ CAA § 301(d)(2)(B), 42 U.S.C. § 7601(d)(2)(B); see also Okla. Tax Comm'n v. Citizen Band

Potawatomi Indian Tribe of Okla., 498 U.S. 505 (1991).

${ }^{203}$ U.S. ENVTL. Prot. Agency, Plan EJ 2014: Legal Tools 76 (2011) [hereinafter Plan EJ 2014], http://www3.epa.gov/environmentaljustice/resources/policy/plan-ej-2014/ej-legal-tools.pdf.

${ }^{204} 63$ Fed. Reg. 7254, 7259 (Feb. 12, 1998). See Montana v. United States, 450 U.S. 544 (1981).

${ }^{205}$ CAA $\S 301(d)(2)(C), 42$ U.S.C. $\S 7601(d)(3)(C)$.

${ }^{206}$ Oliphant v. Squamish Indian Tribe, 435 U.S. 191 (1978); Ute Indian Tribe of the Uintah and Ouray Reservation, 790 F.3d 1000 (10th Cir. 2015).

${ }^{207}$ PlAN EJ 2014, supra note 200, at 78.
} 
TAS status from exposure to citizen suits based on CAA $\S 304,208$ but tribes (or any person) can use the citizen suit provision against sources that are constructed or operated in violation of the CAA or an applicable CAA permit. ${ }^{209}$ In 2005, the SAFETEA-LU transportation legislation in section 10211 limited Oklahoma Indian tribes' TAS authority by requiring an agreement with the state environmental protection agency to jointly administer environmental regulatory programs in order to obtain TAS authority. ${ }^{210}$

The Gila River Indian Community in Arizona in 1999 became the first tribe to obtain TAS status. ${ }^{211}$ The Navajo Nation was a pioneer in taking the responsibility for environmental protection. It was granted TAS and primacy for a program under the Safe Drinking Water Act on October 23, 2000.212 It obtained TAS status under the CAA on October 13, 2004. ${ }^{213}$ The Navajo Nation obtained TAS status for water quality on January 23, 2006 and obtained primacy approval on March 23, 2006.214

On November 9, 2009, President Obama issued a memorandum that reiterated a commitment to collaboration with tribal governments on federal decisions that affect Indians. ${ }^{215}$ The memorandum directed federal agencies to develop plans to implement Executive Order 13,175, which requires coordination with tribal governments on federal actions that impact tribes. ${ }^{216}$ On May 4, 2011, the EPA updated its policy on consultation and coordination. ${ }^{217}$ This policy expands the standards applicable to federal agencies beyond the requirements of Executive Order 13,175. In addition, several EPA Regions have procedures for consultation with Indian tribal governments. ${ }^{218}$

\section{§ 3(B). Tribal Implementation Plans (TIPs)}

A tribe that has obtained TAS status may develop a TIP subject to the EPA's approval. ${ }^{219}$ TIPs provide more flexibility than is the case with a SIP. A TIP allows tribes to address their specific air quality needs and takes into

\footnotetext{
${ }^{208} 63$ Fed. Reg. 7254, 7260 (Feb. 12, 1998).

${ }^{209}$ CAA $\S 304(a), 42$ U.S.C. $\S 7604(a)$.

${ }^{210}$ SAFETEA-LU, Pub. L. No. 109-59, § 10211, 119 Stat. 1144, 1937 (2005).

${ }^{211}$ Milford, supra note 26, at 223.

${ }^{212} 65$ Fed. Reg. 66,541 (Nov. 6, 2000).

${ }^{213} 69$ Fed. Reg. 67,578 (Nov. 18, 2004).

${ }^{214}$ Jill Elise Grant, The Navajo Nation EPA's Experience with “Treatment as a State” and Primacy, 21 NAT. RESOURCES \& ENV'T 9, 12 (2007).

215 Presidential Memorandum on Tribal Consultation (Nov. 5, 2009), 74 Fed. Reg. 57,881 (Nov. 9, 2009).

${ }^{216}$ Exec. Order No. 13,175, supra note 13.

${ }^{217}$ EPA POLICY ON CONSULTATION AND COORDINATION WITH INDIAN TRIBES, supra note 39.

${ }^{218}$ PLAN EJ 2014, supra note, 200 at 74.

${ }^{219}$ CAA $\S 110(\mathrm{k}), 42$ U.S.C. $\S 7410(\mathrm{k})$. See generally William H. Gelles, Tribal Regulatory Authority Under the Clean Air Act, 3 ENVTL. LAW. 363 (1997).
} 
consideration a tribe's capacity to manage an air quality program. ${ }^{220}$ There is no schedule for developing TIP elements and no sanctions for submitting a deficient TIP. ${ }^{221}$ This allows for modular development of a package of subprograms that can include joint tribal and EPA management. ${ }^{222}$ Moreover, other Federal agencies, as well as state, local, and Tribal agencies may regulate for purposes other than compliance with the CAA. Examples include solid waste management, fire safety, and open burning. ${ }^{223}$ By Executive Order each federal agency shall "to the extent practicable and permitted by law, consider any application by an Indian tribe for a waiver of statutory or regulatory requirements in connection with any program administered by the agency...."224

The EPA provides support to tribes to initiate or operate air programs. ${ }^{225}$ By 2002 more than 120 tribes had received grants. ${ }^{226}$ The Administrator of the EPA has promulgated regulations that establish the elements of TIPs and procedures for approval or disapproval of TIPs and portions thereof. ${ }^{227}$ The potential elements of a TIP are: maintenance strategies, attainment strategies, source preconstruction permits, and regional haze plans. ${ }^{228}$

In PSD areas there must be enforceable emission limits for existing sources, emission limits that are adequate to prevent violations, and schedules for implementing emission limits expeditiously. ${ }^{229}$ In nonattainment areas these requirements also apply, but in addition contingency measures must be included to be used if the primary regulations do not result in attainment. ${ }^{230}$ The EPA's NSR program for PSD areas can be delegated to a tribe or a tribe can adopt a program of their own if it meets the EPA's requirements. ${ }^{231}$

In nonattainment areas an NSR program is required and may be developed for the TIP and a minor source NSR program may also be included. ${ }^{232}$ A tribe may include a regional haze plan if visibility issues are a concern. ${ }^{233}$ The last requirement for a tribe seeking approval for a TIP is to demonstrate that it

\footnotetext{
${ }^{220}$ U.S. EnVtl. Prot. AgEnCy, Characteristics of a Tribal Implementation Plan, in DeVELOPING A TRIBAL IMPLEMENTATION PlAN 22 (2002) [hereinafter DEVELOPING A TRIBAL IMPLEMENTATION PLAN], www3.epa.gov/air/tribal/tip2002/.

${ }^{221} I d$. at 23 .

${ }^{222} \mathrm{Id}$. at 22 .

${ }^{223} \mathrm{Id}$. at 24.

${ }^{224}$ Exec. Order No. 13,175, supra note 13, at $\S 6(\mathrm{~b})$.

${ }^{225}$ CAA $\S 105,42$ U.S.C. $\S 7405$.

${ }^{226}$ Milford, supra note 26, at 213-214.

${ }^{227}$ U.S. Envtl. Protection Agency, Indian Tribes: Air Quality Planning and Management, 63 Fed. Reg. 7254 (Feb. 12, 1998) (codified at 40 C.F.R. § 71.2); see also 40 C.F.R. $\S 49.6(a)$. The TAR rule that provides for Tribal Authority is found at 40 C.F.R. pt. 49.

${ }^{228}$ DEVELOPING A TRIBAL IMPLEMENTATION PLAN, supra note 217, at 26.

${ }^{229}$ Id.; see also CAA $\S 110(\mathrm{a})(2)(\mathrm{D}), 42$ U.S.C. $\S 7410(\mathrm{a})(2)(\mathrm{D})$.

${ }^{230}$ DeVEloping A TRIBAL IMPLEMENTATION PlAn, supra note 217, at 28.

${ }^{231} I d$. at 29.

${ }^{232}$ Id.

${ }^{233} \mathrm{Id}$. at 30.
} 
has enforcement authority that meets the EPA's expectations. ${ }^{234}$ Federal enforcement of the CAA on Indian lands is not always aggressive. For example, the Bonanza Power Plant owned by Desert Power is located on Utah's UintahOuray reservation. The Ute Indian Tribe and environmentalists have uncovered more than 35,000 violations of the CAA by the plant. ${ }^{235}$

According to the EPA, in 2014 most tribes with TAS status were administering one or more parts of the CAA for the EPA, but only three tribes were approved to implement TIPs, and only one tribe had been delegated the authority to implement a Title $\mathrm{V}$ operating permit program. ${ }^{236}$ On October 30 , 2007, the EPA announced the Saint Regis Mohawk tribe in New York State had become the first tribe to have an EPA approved tribal implementation plan (TIP)..$^{237}$

The Gila River Indian Community was delegated responsibility for administering the EPA's Title V operating program on October 15, 2004. On January 19, 2011, the EPA approved the Gila River TIP. ${ }^{238}$ The Gila River TIP is the most comprehensive TIP in the nation, and includes a minor source permit program and mechanisms for administrative and tribal judicial review. ${ }^{239}$ The Southern Ute Reservation in Colorado includes approximately 700,000 acres of land and its forty-two major sources are about one-third of the major sources in Indian country; it also has an estimated 1,000 minor sources of air pollution. ${ }^{240}$ On March 12, 2012, the Southern Ute Indian Tribe became the first tribe with the authority to administer a Title V, 40 C.F.R. Part 70 operating permit program. ${ }^{241}$ The Navajo Nation had previously been delegated responsibility for administering an operating permit program under 40 C.F.R. Part $71 .^{242}$

\footnotetext{
${ }^{234}$ Id.; see also 40 C.F.R. pt. 51, app. V.

${ }^{235}$ Ute Indian Tribe, Wildearth Guardians Join Forces for Clean Air, Public Health in Utah's Uinta Basin, WiLDEARTH (Apr. 25, 2012),

http://www.wildearthguardians.org/site/News2?page=NewsArticle\&id=7613\#.VsjGtfkrKM8.

${ }^{236}$ Plan EJ 2014, supra note, 200 at 20; Basic Information, U.S. ENVTL. PROTECTION AGENCY, http:/www3.epa.gov/air/tribal/backgrnd.html (last visited Sept. 28, 2015). The three tribes with TIP authority are the Mohegan Tribe of Connecticut, the Saint Regis Mohawk Tribe, and the Gila River Indian Community. Baehr-Jones \& Cheung, supra note, 81 at 207.

${ }^{237}$ Gerald B. Silverman, St. Regis Mohawks First Tribe to Receive EPA Approval for Tribal Implementation Plan, 38 ENV'T REP. (BNA) 2335 (Nov. 2, 2007); see U.S. Envtl. Protection Agency, Approval and Promulgation of Saint Regis Mohawk's Tribal Implementation Plan, 72 Fed. Reg. 45,397, 45,400 (proposed Aug. 14, 2007); 72 Fed. Reg. 69,618 (Dec. 10, 2007) (final rule)

${ }^{238}$ U.S. Envtl. Protection Agency, Approval and Promulgation of Gila River Indian Community's Tribal Implementation Plan, 75 Fed. Reg. 48,880 (Aug. 12, 2010) (proposed rule); 76 Fed. Reg. 17,028 (Apr. 27 , 2011) (final rule).

${ }^{239}$ Baehr-Jones \& Cheung, supra note 81, at 209.

${ }^{240}$ Sam W. Maynes, Air Pollution Control on the Southern Ute Indian Reservation, 42 CoLO. LAW. 8:85, 86 (2013).

${ }^{241}$ Clean Air Act (CAA) Full Approval of Title V Operating Permits Program, Southern Ute Indian Tribe, 77 Fed. Reg. 15,267 (2012).

242 Maynes, supra note 237.
} 
Nevertheless, few tribes have tribal air pollution codes. In 2014, Professor Elizabeth Warner, examined the environmental laws of 74 of the 566 recognized tribes, which included 29 percent of the nation's native American population. ${ }^{243}$ The tribes surveyed were located in Oklahoma, New York, Montana and Arizona. Her study discovered that only five percent of the survey group had enacted tribal air pollution laws. ${ }^{244}$ They were the Cherokee Nation, the Gila River Indian Community, the St. Regis Mohawk Tribe, and the part of the Navajo Nation in Arizona. ${ }^{245}$ The Navajo Nation has the most comprehensive air pollution regulations that generally follow the CAA.246

\section{$\S 3(C)$. The Jurisdictional Reach of a TIP}

An important issue is the jurisdictional reach of a tribe with TAS status that have an approved TIP. It may regulate all areas within the exterior boundaries of a reservation including areas held in fee. ${ }^{247}$ It includes all dependent Indian communities, and all Indian allotments to which Indian title has not been extinguished.248 On March 3, 1998, the Ninth Circuit decided Montana v. EPA. ${ }^{249}$ Montana challenged the EPA's decision to grant TAS status to regulate all sources of water pollutant discharges within the boundaries of the Reservation, regardless of whether the sources are on land owned by members or non-members of the Tribe. The Ninth Circuit supported the EPA's TAS rule that allows control of the activities of non-members on non-Indian fee lands if the regulated activity affects "the political integrity, the economic security, or the health or welfare of the tribe."250 The potential impacts of the activities on the tribe must be "serious and substantial" to allow tribes to regulate non-members.

As discussed previously, the CAA's PSD program allows tribes to exercise power over development beyond the exterior boundaries of the reservation. ${ }^{251}$ Empowering Indian tribes with the ability to conduct their own air programs can impact emission sources in and near the Indian lands because it creates another regulatory entity that will impose regulations on existing or potential emission sources. Moreover, TAS status makes a tribe an "affected state," which allows it to

\footnotetext{
${ }^{243}$ Elizabeth K. Warner, Examining Tribal Environmental Law, 39 CoLUM. J. ENVTL. L. 42, 66 (2014).

${ }^{244} I d$. at 68 .

${ }^{245} \mathrm{Id}$.

${ }^{246}$ Id. at $74-81$.

${ }^{247}$ CAA $\S 110($ o), 42 U.S.C. $7410(0)$.

${ }^{248}$ U.S. Envtl. Protection Agency, Indian Tribes: Air Quality Planning and Management, 63 Fed. Reg. 7254 (Feb. 12, 1998) (codified at 40 C.F.R. $\S 71.2$ ); 40 C.F.R. pts. 9, 35, 49, 50, 81; see also 40 C.F.R. $\S$ 49.6(a).

${ }^{249} 137$ F.3d 1135 (9th Cir. 1998).

${ }^{250} 40$ C.F.R. $\S 131.8($ b)(3). For a case holding that this standard had not been met see Bugenig v. Hoops Valley Tribe, 293 F.3d 1210 (9th Cir. 2000).

${ }^{251}$ See supra $\S 2(\mathrm{c})$.
} 
comment on draft operating permits proposed by neighboring state permitting authorities. ${ }^{252}$

It may be possible to extend the off-reservation reach of the CAA based on decisions under the CWA. On October 7, 1996, the Tenth Circuit decided Albuquerque v. Browner. ${ }^{253}$ The city of Albuquerque filed a complaint challenging EPA's approval of the Pueblo of Isleta's water quality standards. The district court granted summary judgment to the EPA, and Albuquerque appealed. This case was the first challenge to water quality standards adopted by an Indian tribe under the 1987 amendments to the CWA's $\S 518(\mathrm{e})$ that allow Indian tribes to be treated as states. ${ }^{254}$ The Isleta Pueblo adopted water quality standards more stringent than New Mexico's standards, which were subsequently approved by the EPA. This affected Albuquerque's waste treatment facility because the city was required to revise its NPDES discharge permit to meet the downstream Isleta's water quality standards. The issue before the court was whether the EPA could impose Isleta's standards on an upstream discharger. The Tenth Circuit held that Indian tribes may establish water quality standards more stringent than those imposed by the federal government, and it affirmed the granting of summary judgment to EPA. Moreover, the U. S. Supreme Court has held that the EPA has the authority to require upstream NPDES discharges to comply with downstream state water quality standards. ${ }^{255}$ If a tribe has a FIP, this Supreme Court decision could support a tribe's claims to restrict upwind emissions that affect its air quality.

\section{§ 3(D). Delegation}

A tribe, with or without TAS status, as an alternative to developing a TIP, may seek to have federal air pollution programs delegated to it for implementation. ${ }^{256}$ In 1975 the U.S. Supreme Court upheld the power of Congress to allow the delegation of authority to a tribe. ${ }^{257}$ The EPA has a well-established processes for delegating federal authority to states and/or Tribes for administering Federal rules under the Act, including conducting NSR under 40 C.F.R. $\S 52.21(\mathrm{u})$ and issuing federal operating permits under 40 C.F.R. $\S \S 71.4(\mathrm{j})$ \& 71.10. For example, in 2004 the EPA delegated authority to the Navajo Nation to allow it to administer the 40 C.F.R. Part 71 federal operating permit program, but excluded the Four Corners Power Plant and the Navajo Generating Station. ${ }^{258}$

\footnotetext{
${ }^{252}$ CAA $\S 505(a), 42$ U.S.C. $\S 7661 a(a)$.

25397 F.3d 415 (10th Cir. 1996).

25433 U.S.C. $\S 1377(\mathrm{e})$.

${ }^{255}$ Albuquerque, 97 F.3d at 424 (citing Arkansas v. Oklahoma, 503 U.S. 91, 102 (1992)).

25676 Fed. Reg. 38,748, 38,780 (July 1, 2011).

${ }^{257}$ United States v. Mazurie, 419 U.S. 544 (1975).

${ }^{258}$ Announcement of the Delegation of the Title V Permitting Program, Consistent With Federal Operating Permit Program to the Navajo Nation Environmental Protection Agency and the Suspension of Federal
} 
On April 8, 2005, the EPA finalized a FIP for 39 Indian reservations in Idaho, Oregon, and Washington. ${ }^{259}$ The EPA is willing to delegate certain administrative authority to the Tribes, but it maintains it has the sole authority to enforce, and such actions would be subject to EPA's appeal procedures. The delegation was pursuant to 40 C.F.R. $\S$ 49.122(a). The criteria for delegation is found in 40 C.F.R. $\S 49.122(\mathrm{~b})$. The EPA has explained that a number of rules under the CAA will not be delegated. ${ }^{260}$ If delegation is approved, a Partial Delegation of Administrative Authority Agreement between the Administrator and the Tribal agency will contain the terms and conditions of the delegation and specify the rules and provisions the Tribal agency is authorized to implement. ${ }^{261}$

The delegation of the authority to assist EPA with administration of elements of the federal NSR programs is a process that differs from approval of Tribal eligibility and Tribal programs under CAA $\S 301(\mathrm{~d})$ and the TAR. Tribes requesting to assist EPA through administrative delegation need not demonstrate congressionally-delegated authority within the exterior boundaries of their reservations or authority over non-reservations areas of Indian country. Tribes only need to show that their laws provide adequate authority to perform the delegated activities. ${ }^{262}$

Administratively delegated programs will continue to be enforced by the EPA, not the delegated Tribal agency. Administrative appeals of permitting decisions will also continue to be made directly to the Environmental Appeals Board (EAB) with any subsequent judicial review to be conducted in Federal court. ${ }^{263}$ EPA does not believe that it would be appropriate to delegate enforcement of a Federal permit in Federal court to an Indian Tribe assisting EPA with administration of the NSR program. EPA has consistently withheld the authority to seek enforcement in federal courts by any administratively delegated entity, whether a state or a Tribe. ${ }^{264}$ Tribes operating under delegated authority cannot charge permit fees, but tribes implementing TIPs can impose fees. ${ }^{265}$

For many tribes delegation is the better route to expand their ability to control air pollution, because of the expense, expertise, and time required to meet the EPA's requirements for a TIP. 266 The Southern Ute Tribes TIP-based operating permit program, for example, required years to complete, required

Operating Permit Fee Collection by EPA for Sources Covered by the Delegation of Authority Agreement, 69 Fed. Reg. 67,578 (Nov. 18, 2004). See generally Grant, supra note 211.

${ }^{259}$ U.S. Envtl. Protection Agency, Federal Implementation Plans Under the Clean Air Act for Indian Reservations in Idaho, Oregon and Washington, 70 Fed. Reg. 18,074 (Apr. 8, 2005).

${ }^{260} \mathrm{Id}$. at 18,081 .

26176 Fed. Reg. 38,748, 38,781 (July 1, 2011).

${ }^{262} I d$. at 38,780 .

${ }^{263} \mathrm{Id}$. at 38,781 .

${ }^{264} I d$. at 38,782 .

${ }^{265} \mathrm{Id}$.

${ }^{266}$ Grant, supra note 211, at 14-15. 
hiring and training of staff with the necessary expertise, and involved substantial "up front" costs. 267

\section{§ 4. Oil \& Gas Regulation in Indian Country}

Indian lands may be leased for mineral development pursuant to three federal laws. The Mineral Leasing Act of 1938 provides for Indian lands to be leased for ten years, or longer, with the consent of the Secretary of the Interior. ${ }^{268}$ The Indian Mineral Development Act of 1982 allows tribes to enter into mineral development agreements subject to the approval of the Secretary of the Interior. ${ }^{269}$ In the Energy Policy Act of 2005, Congress included the Indian Tribal Energy Development and Self-Determination Act (ITEDSA). ${ }^{270}$ This Act allows a tribe to enter into tribal energy resource agreements (TERAs) with the Department of the Interior if the tribe demonstrates its capacity to regulate the development of tribal resources. ${ }^{271}$ The TERA process includes an environmental review. ${ }^{272}$ However, as of 2015 there were no TERAS in existence. ${ }^{273}$ This may in part be due to the complexity of the TERA process, the high costs imposed on applicants by the Department of the Interior, and the problems created by the ownership of the surface and subsurface being held by different people. ${ }^{274}$

The EPA's regulations applicable to oil and gas operations include NSPS for the oil and gas industry, discussed below, and NSPS for specific equipment including compression ignition and spark ignition engines. ${ }^{275}$ Oil and gas facilities must also comply with the National Emission Standards for Hazardous Air Pollutants (NESHAPs) such as the rule for reciprocating internal combustion engines used in their operations. ${ }^{276}$ Oil and Gas operations on Indian lands require an Application for a Permit to Drill (APD) to be submitted and approved by the BLM.277 Moreover, there are additional voluntary programs for the industry aimed at reducing their air pollution emissions. ${ }^{278}$

\footnotetext{
${ }^{267}$ Maynes, supra note 237, at 88-89.

${ }^{268}$ Act of May 11, 1938, Pub. L. No. 506, 52 Stat. 347 (codified as amended at 25 U.S.C. § 396(a)-(g).

26925 U.S.C. $\$ 2102(\mathrm{a})$.

27025 U.S.C. $\S \S 3501-3506$.

27125 U.S.C. $\$ 3504(\mathrm{e})$.

27225 U.S.C. $\$ 3504(\mathrm{e})(2)(\mathrm{B})(\mathrm{iii})(\mathrm{IX})$.

${ }^{273}$ U.S. GOV'T ACCOUNTABILITY OFF., GAO-15-502, INDIAN ENERGY DEVELOPMENT 34 (2015).

${ }^{274}$ Kemp, supra note 6; Tanana \& Ruple, supra note 26, at 38-39.

${ }^{275}$ U.S. Envtl. Protection Agency Standards of Performance for Stationary Compression Engines and Spark Ignition Internal Combustion Engines, 76 Fed. Reg. 37,954 (June 28, 2011).

${ }^{276}$ See supra notes $125-132$ and accompanying text.

27725 U.S.C. $\S 396 d ; 43$ C.F.R. $\S 3162$.

${ }^{278}$ See Bridget DiCosmo, EPA Scales Back Voluntary Methane Program, Piquing Advocates, 27 CLEAN AIR REP. (Inside EPA) 3:9 (Feb. 11, 2016).
} 


\section{§ 4(A). NSPS/HAPS}

An important EPA regulation is the 2012 NSPS/HAP regulation for the Crude Oil and Natural Gas Production and Onshore Natural Gas Processing Plant source category. ${ }^{279}$ The NSPS apply to well completions, pneumatic controllers, equipment leaks from natural gas processing plants, sweetening units at natural gas processing plants, compressors, and storage vessels that begin construction, modification or reconstruction after August 23, 2011.280 Well completions after January 1, 2015, are subject to the NSPS during the flowback period following hydraulic fracturing operations at a gas well affected facility. These completions include those conducted at newly drilled and fractured wells, as well as completions conducted following refracturing operations that may occur at various times over the life of the well. The NSPS also applies to onshore sweetening units that process natural gas from onshore or offshore wells.

The NSPS for the Crude Oil and Natural Gas Production source category sets performance standards that limit VOC emissions from gas wells, centrifugal compressors, reciprocating compressors, pneumatic controllers, storage vessels and leaking components at onshore natural gas processing plants, as well as sulfur dioxide $\left(\mathrm{SO}_{2}\right)$ emissions from onshore natural gas processing plants. ${ }^{281}$ The rule regulates onshore gas wells drilled principally for production of natural gas, but it does not regulate wells drilled principally for the production of crude oil. Fractured and refractured gas wells are required to use reduced emissions completions, also known as "RECs" or "green completions," to reduce VOC emissions. This may involve the use of a combustion device to limit VOC emissions. ${ }^{282}$

Individual storage vessels in the oil and natural gas production segment and the natural gas processing, transmission and storage segments with VOC emissions equal to or greater than six tpy must achieve at least 95.0 percent emissions reduction. ${ }^{283}$ Pneumatic controllers located between the wellhead and the point at which the gas enters the transmission and storage segment have natural gas bleed limits. ${ }^{284}$ Centrifugal compressors have VOC reduction requirements. ${ }^{285}$ For onshore natural gas processing plants, the NSPS

\footnotetext{
${ }^{279}$ U.S. Envtl. Protection Agency, Oil and Natural Gas Sector: New Source Performance Standards and National Emission Standards for Hazardous Air Pollutants Reviews, 77 Fed. Reg. 49,490 (Aug. 16, 2012) (codified at 40 C.F.R. Pt. 60, Subpt. OOOO and 40 C.F.R, Pt. 63, Subpts HH \& HHH). Amendments and correction of technical errors were made at 79 Fed. Reg. 79,018 (Dec. 31, 2014).

${ }^{280}$ See generally EnERgy InFo. Admin., OfFICE OF OIL \& GAS, NATURAL GAS Processing: THE CRUCIAL

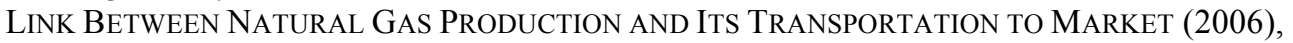
https://www.eia.gov/pub/oil_gas/natural_gas/feature_articles/2006/ngprocess/ngprocess.pdf.

${ }^{281} 77$ Fed. Reg. at $44,492$.

${ }^{282} I d$.

${ }^{283} \mathrm{Id}$

${ }^{284} \mathrm{Id}$

${ }^{285} \mathrm{Id}$.
} 
requirements for leak detection and repair (LDAR) and $\mathrm{SO}_{2}$ emissions are made more stringent. ${ }^{286}$

The regulation also provides National Emissions Standards for Hazardous Air Pollutants (NESHAP) for the Oil and Natural Gas Production source category and the Natural Gas Transmission and Storage source category. In addition, the EPA has established MACT standards for specified emission sources in the oil and gas industry. ${ }^{287}$ Major sources at oil and natural gas production facilities may be subject to the NESHAP for glycol dehydration units, which includes MACT standards for "small" glycol dehydration units that include specific limits for benzene, ethylbenzene, toluene and xylene (BTEX). ${ }^{288}$

There are significant tribal interests in the emissions standards because of the growth of the oil and gas production industry in Indian country. Executive Order 13,175 sets some limits on the authority of any agency, including the EPA. ${ }^{289}$ It holds that the EPA may not issue a regulation that has tribal implications, that imposes substantial direct compliance costs, and that is not required by statute, unless the Federal government provides the funds necessary to pay the direct compliance costs incurred by tribal governments, or the EPA consults with tribal officials early in the process of developing the proposed regulation and develops a tribal summary impact statement. The EPA concluded the regulation would not have tribal implications because it doesn't impose a significant cost on a tribe. 290

The EPA initiated a consultation process with tribal officials early in the process of developing this regulation. It conducted outreach and information meetings prior to the proposal in 2010 and met with tribal leaders. After the proposal was published, letters were sent to all tribal leaders offering to consult on a government-to-government basis on the rule. As part of the consultation process and in response to these letters, an outreach call was held on October 12, 2011. Tribes that participated included the Southern Ute Indian Tribe. Comments on the proposal were received from an affiliate of the Southern Ute Indian Tribe. The commenter expressed concern about the impacts of the rule on natural gas and oil production operations on the Southern Ute Indian reservation and requested additional time to evaluate the impacts. In response to this and other requests, the comment period was extended. More specific comments can be found in the docket. ${ }^{291}$

\footnotetext{
${ }^{286} \mathrm{Id}$.

${ }^{287}$ Id. at 44,491 .

${ }^{288} I d$. at $44,492$.

${ }^{289} 65$ Fed. Reg. 13175 (Nov. 9, 2000).

${ }^{290}$ U.S. Envtl. Protection Agency, Oil and Natural Gas Sector: New Source Performance Standards and National Emission Standards for Hazardous Air Pollutants Reviews, 77 Fed. Reg. 49,490, 49,539 (Aug. 16. 2012); U.S. Envtl. Protection Agency, Oil and Natural Gas Sector: Reconsideration of Additional Provisions of New Source Performance Standards, 79 Fed. Reg. 79,018 (Dec. 31, 2014). ${ }^{291} I d$.
} 


\section{§4(B). Oil and Natural Gas Sector: Emission Standards for New and Modified Sources}

Methane is a greenhouse gas (GHG) with 25 times the global warming potential of $\mathrm{CO}_{2}$, and the oil and natural gas industrial category is the single most important U.S. emission source with nearly one-third of the nation's emissions. 292 On September 18, 2015, the EPA proposed amendments to the NSPS for the oil and gas sources category to expand the coverage of oil and gas VOC emissions to include controls on methane emissions. ${ }^{293}$ The EPA finalized the proposed on June 3,2016 . The changes to the NSPS are applicable to new, reconstructed and modified oil and gas operations. ${ }^{294}$ The amendments impose standards for both greenhouse gases and VOCs and add requirements for operations and equipment covered by the 2012 standards. ${ }^{295}$ These implementation improvements do not change the requirements for operations and equipment covered by the current standards at 40 C.F.R. part 60, subpart 0000. ${ }^{296}$ The amendments will apply to hydraulically fractured oil wells well completions, pneumatic pumps, and fugitive emissions from well sites and compressor stations that are not regulated by the 2012 rules; hydraulically fractured gas well completions and equipment leaks at natural gas processing plants that are currently regulated for VOC are now subject to GHG regulations. ${ }^{297}$

The 2016 rule adds new requirements for detecting and repairing leaks at natural gas well sites. Leaks, known as fugitive emissions, must be repaired within thirty days, but if a repair would shut down production additional time for the repair is allowed. ${ }^{298}$ Leak monitoring plans must be developed using optical gas imaging equipment or by using a portable VOC monitoring instrument as specified in EPA's Method 21. ${ }^{299}$ The leak monitoring will apply to valves, connectors, pressure relief devices, open-ended lines, flanges, closed vent systems, compressors and other components. ${ }^{300}$ However, some wellheads that

\footnotetext{
${ }^{292}$ Tripp Baltz, States Target Fugitive Methane Emissions From Oil, Gas Before Federal Agencies Act, 47 ENV'T REP. (BNA) 1947 (JUNE 24, 2016).

${ }^{293}$ U.S. Envtl. Protection Agency, Oil and Natural Gas Sector: Emission Standards for New and Modified Sources, 80 Fed. Reg. 56,593 (proposed Sept. 18, 2015).

${ }^{294}$ U.S. Envtl. Protection Agency, Oil and Natural Gas Sector: Emission Standards for New and Modified Sources, 81 Fed. Reg. 35,824 (June 3, 2016) (amending 40 C.F.R. part 60, subpt. OOOO and proposing new standards at subpart OOOOa).

${ }^{295}$ Id. at 35,826 .

${ }^{296} I d$. at 35,826 .

${ }^{297}$ Id.

${ }^{298}$ Summary of Requirements for Processes and Equipment At Naural Gas Well Sites, https://www3.epa.gov/airquality/oilandgas/may2016/nsps-gas-well-fs.pdf (May12, 2016).

${ }^{299} I d$.

${ }^{300} I d$.
} 
contain only "Christmas trees" are exempt. ${ }^{301}$ The rule also adds new requirements for diaphragm pumps used at well sites. ${ }^{302}$

The amendments to the NSPS rule also requires a monitoring plan to be developed and implemented to control leaks at gathering and boosting compressor stations that obtain gas from multiple wells and move it to a natural gas processing plant. ${ }^{303}$ Because the best system for reducing methane is the same as is used to reduce VOC emissions, the requirements for centrifugal and reciprocating compressors, pneumatic controllers, and storage tanks continue to be regulated by the 2012 NSPS. ${ }^{304}$ However, the 2016 update limits methane and VOC emissions from wet seal centrifugal compressors from the oil and gas industry, except for those located at well sites. A 95 percent reduction of methane and VOC emissions is required by utilizing either flaring or by routing captured gas back to the processor. Dry seal centrifugal compressors are not covered by the final rule because they have low methane and VOC emissions. Reciprocating compressors, except for those located at well sites, are to have the rod packing replaced based on specified hours of operation or elapsed calendar months or by routing emissions from the rod packing through a closed vent system under negative pressure to be reused or recycled by a process or a piece of equipment. ${ }^{305}$ Pneumatic controllers used to maintain liquid levels, pressure and temperature that are powered by high pressure natural gas. Continuous bleed pneumatic controllers now have a natural gas bleed rate limit of 6 standard cubic feet per hour (scfh). Low-bleed controllers with a gas bleed rate of $6 \mathrm{scfh}$ or less have no new requirements. EPA did not finalize requirements for pneumatic pumps at compressor stations. Storage tanks also do not have new requirements, but continue to be regulated by the 2012 NSPS requirements. ${ }^{306}$

Natural gas processing plants have new requirements for controlling emissions from pneumatic pumps. Natural gas-driven piston pumps are not subject to new rules nor are diaphragm pumps powered by electricity, compressed air or solar power. Processing plants continue to be regulated primarily by the 2012 NSPS. ${ }^{307}$

Requirements imposed by states (and tribes) that are at least as protective as federal requirements can be used to demonstrate compliance with the federal

\footnotetext{
${ }^{301} I d$.

${ }^{302} \mathrm{Id}$.

${ }^{303}$ Summary of Requirements For Process and Equipment At Natural Gas Production Gathering and Boosting Stations, https:/www3.epa.gov/airquality/oilandgas/may2016/nsps-gas-production-fs.pdf (May 12, 2016).

${ }^{304} \mathrm{Id}$.

${ }^{305}$ Summary of Requirements For Equipment At Natural Gas Transmission Compressor Stations, https://www3.epa.gov/airquality/oilandgas/may2016/nsps-gas-transmission-fs.pdf (May 12, 2016). ${ }^{306} \mathrm{Id}$.

${ }^{307}$ Summary of Requirements For Process and Equipment At Natural Gas Processing Plants, https://www3.epa.gov/airquality/oilandgas/may2016/nsps-gas-processing-fs.pdf (May12, 2016).
} 
rule. ${ }^{308}$ Facilities that will be subject to the proposed EPA standards may also be subject to current or future requirements of the Department of Interior's Bureau of Land Management (BLM), which regulates the production of natural gas on Federal lands. Therefore EPA and BLM will continue to coordinate their regulatory requirements. ${ }^{309}$

The EPA's regulation of methane emissions from oil and gas wells was challenged by North Dakota in the D.C. Circuit on July 15, 2016. ${ }^{310}$ Subsequently about 14 states joined the lawsuit as well as numerous industry organizations. 311 This was followed by nine states and numerous environmental groups intervening to support EPA's section 111(b) rule. ${ }^{312}$

The "Source Determination Rule," promulgated June 3, 1916, will lead to more oil and gas facilities being considered major sources. ${ }^{313}$ The new rule applies to onshore oil and natural gas production and natural gas processing. The Prevention of Significant Deterioration Program (PSD) preconstruction permit requirements, the Nonattainment New Source Review (NNSR) preconstruction permit program, and the Title $\mathrm{V}$ operating permit program apply to major sources. ${ }^{314}$ Sources in the same industrial group (the same two-digit SIC code), under common control and located on contiguous or adjacent properties are to be aggregated. ${ }^{315}$ The EPA's final rule clarifies the term adjacent, which determine when minor sources are to be aggregated to create a major source. Multiple sources are to be aggregated to produce a major emitting facility if they are on the same site, or are on sites that share equipment and are within onequarter of a mile of each other. ${ }^{316}$

The EPA is not requiring that EPA-approved state and local programs adopt the approach in the "Source Determination Rule." This allows state and local permitting authorities that have programs approved by the EPA to continue to make source determinations for the oil and gas industry in the manner that they believe best addresses their local air quality concerns. However, states that administer PSD permitting programs under a delegation of federal authority will have to follow the approach of the "Source Determination Rule" or develop their

\footnotetext{
${ }^{308} 81$ Fed. Reg. at 35,871.

${ }^{309}$ See $\S 4($ E) infra.

${ }^{310}$ Anthony Adragna, North Dakota First to Sue EPA Over Rule Targeting Oil, Gas Well Methane Emissions, 47 ENV;T REP. (BNA) 2186 (July 22, 2016).

${ }^{311}$ Anthony Adragna, EPA Methane Rule for New, Modified Sources Faces More Challenges From States, Industry, 47 ENV'T REP. (BNA) 2311 (Aug. 5, 2016)

${ }^{312}$ Anthony Adragna, Nine States, Environmental Groups Back EPA in Legal Battle Over Methane Regulations. 47 ENV'T REP. (BNA) 2446 (Aug. 19, 2016).

${ }^{313}$ U.S. Envtl. Protection Agency, Source Determination for Certain Emission Units in the Oil and Natural Gas Sector, 81 Fed. Reg. 35,622 (June 3, 2016).

${ }^{314} \mathrm{Id}$.

${ }^{315} \mathrm{Id}$. at 35,623. See also 40 C.F.R. $\$ 51.165(\mathrm{a})(1)(\mathrm{ii}) ; 51.166(\mathrm{~b})(6)$.

${ }^{316} \mathrm{Id}$. at 35,624. See also Clarification of Air Permitting Rules for the Oil and Gas Industry: Fact Sheet, $<$ https:/www3.epa.gov/airquality/oilandgas/may2016/source-determination-fs.pdf> (May 12, 2016).
} 
own permitting programs and have them approved by as a revision to a state implementation plan (SIP). ${ }^{317}$

The "Source Determination Rule" is also expected to produce HAP reductions and will benefit areas that approach or exceed the NAAQS for ozone. There have been measurements of increasing ozone levels in areas with concentrated oil and natural gas activity, including Wyoming and Utah. Several VOCs emitted in the oil and natural gas source category are HAPs listed under CAA $\S 112(\mathrm{~b})$, including benzene, toluene, ethylbenzene and xylenes (this group is commonly referred to as "BTEX") and n-hexane. ${ }^{318}$

\section{§ 4(C). The 2016 FIP}

On September 18, 2015, the EPA promulgated a proposed FIP to regulate new true minor sources and minor modifications at true minor sources involved in the production of oil and natural gas and in the processing of natural gas. On June 3, 2016, the EPA promulgated the finalized the rule. ${ }^{319}$ The oil sector includes the operations from the well to the point of custody transfer to an oil pipeline or other means of transportation to a petroleum refinery. For natural gas, the sector includes all operations from the well to the final end user. ${ }^{320}$ "The oil and natural gas sector can generally be separated into four segments: (1) Oil and natural gas production; (2) natural gas processing; (3) natural gas transmission and storage; and (4) natural gas distribution." ${ }^{321}$ The FIP applies throughout Indian country, except non-reservation areas, unless a tribe or EPA demonstrates jurisdiction for those areas. ${ }^{322}$ True minor sources are those that have the potential to emit below the major source threshold by design, while synthetic minor sources are restricted to emissions below the major source threshold by the terms of their permit. ${ }^{323}$

The FIP will be used instead of source-specific minor source preconstruction permits for true minor sources in the oil and natural gas production and natural gas processing segments of the oil and natural gas sector in areas covered by the Indian Country Minor NSR rule if there is no

\footnotetext{
${ }^{317} I d$. at 35,626 .

${ }^{318}$ U.S. Envtl. Protection Agency, Review of New Sources and Modifications in Indian County: Federal Implementation Plan for Managing Air Emissions from True Minor Sources Engaged in Oil and Natural Gas Production in Indian Country, 80 Fed. Reg. 56,554, 56,596 (Sept. 18, 2015).

${ }^{319}$ U.S. Envtl. Protection Agency, Federal Implementation Plan for True Minor Sources in Indian Country in the Oil and Natural Gas Production and Natural Gas Processing Segments of the Oil and Natural Gas Sector; Amendments to the Federal Minor New Source Review Program in Indian Country To Address Requirements for True Minor Sources in the Oil and Natural Gas Sector, 81 Fed. Reg. 35,944 (June 3, 2016).

${ }^{320}$ Federal Plan for Implementing the Indian Country Minor Source Review Program for the Industry: Fact Sheet, https://wwwe.epa.gov/oilandgas/may2016/fip-fact-sheet.pdf (May 12, 2016).

${ }^{321} 81$ Fed. Reg. at 35,952

${ }^{322}$ Review of New Sources and Modifications in Indian Country, supra note 313, at 56,554.

${ }^{323} 81$ Fed. Reg. at 35,951.
} 
applicable EPA-approved program with legally and practicably enforceable requirements to control and reduce air emissions from such sources. ${ }^{324}$ The EPA believes the issuance of source-specific permits has the potential to overwhelm the system, and a FIP is the most appropriate way of implementing the Federal Indian Country Minor NSR rule. ${ }^{325}$ The FIP does not apply in areas that are nonattainment for a NAAQS. ${ }^{326}$ In nonattainment areas true minor sources will require either a site-specific minor NSR permit or compliance with a reservation specific FIP if one exists. ${ }^{327}$ Sources covered by the Federal Indian Country Minor NSR rule that do not meet all of the eligibility criteria must obtain a site-specific permit prior to beginning construction, on or after October 3, 2016. A source owner/operator that does not want to comply with the FIP also has the option to apply for a site-specific permit. ${ }^{328}$ True minor sources are generally subject to the applicable provisions of the standard as written at the time construction or reconstruction of the source is begun. ${ }^{329}$ Major sources continue to be regulated by the more complex NSR permit program. To accommodate the FIP, the Indian Country Minor NSR rule has been updated.

The FIP incorporates emission limits and other requirements from the following eight federal standards:

NSPS for the oil and natural gas industry issued May 12, 2016;

Performance standards for VOC emissions from liquid storage tanks;

Performance standards for stationary compression ignition internal combustion engines (diesels);

Performance standards for spark ignition internal combustion engines;

Performance standards for new stationary combustion turbines;

Air toxic standards for industrial, commercial and institutional boilers and process heaters;

Air toxic standards for oil and natural gas production facilities; and

Air toxic standards for stationary reciprocating internal combustion engines. ${ }^{330}$

The regulations are imposed on production and processing components may include, but are not limited to, "wells and related casing head; tubing head and 'Christmas tree' piping; pumps; compressors; heater treaters; separators; storage vessels; pneumatic devices; stationary engines; natural gas sweetening; truck loading; dewpoint suppression skids; natural gas dehydrators; completion and workover processes; gathering pipelines and related components that collect and transport the oil, natural gas and other materials and wastes from the wells

\footnotetext{
${ }^{324} 81$ Fed. Reg. at 35,952.

${ }^{325} \mathrm{Id}$.

${ }^{326} 81$ Fed. Reg. at 35,946.

${ }^{327}$ Id.

${ }^{328} \mathrm{Id}$.

${ }^{329} 81$ Fed. Reg. at 35,944.

${ }^{330} 81$ Fed. Reg. at 35,946.
} 
or well pads; and natural gas processing plants." 331

Production operations also include the well drilling, completion and workover processes and include all the portable non-self-propelled apparatuses associated with those operations. Production sites include not only the sites where the wells themselves are located, but also include centralized gas and/or liquid gathering facilities where oil, condensate, produced water, and natural gas from several wells may be separated, stored, and treated. The production segment also includes the low to medium pressure, smaller diameter, gathering pipelines and related components that collect and transport the oil, natural gas and other materials and wastes from the wells or well pads." 332

The natural gas production segment ends at the natural gas processing plant. If there is no processing plant, the production segment ends where the natural gas enters the transmission segment for long-line transport. The crude oil production segment ends where custody is transferred to an oil pipeline or for transport of the crude oil to a petroleum refinery. Pollutants emitted from new and modified minor sources and minor modifications of major sources in areas covered by the Federal Indian Country Minor NSR rule include: $\mathrm{VOC}, \mathrm{NO}, \mathrm{SO}_{2}$, $\mathrm{PM}, \mathrm{PM}_{10}, \mathrm{PM}_{2.5}, \mathrm{H}_{2} \mathrm{~S}, \mathrm{CO}$ and various sulfur compounds. ${ }^{33}$ Hydrogen sulfide $\left(\mathrm{H}_{2} \mathrm{~S}\right)$ and $\mathrm{SO}_{2}$ are emitted from production and processing operations that handle and treat sour gas. ${ }^{334}$

In addition to air emission control requirements, the EPA requires true minor sources to assess their impacts on threatened and endangered species and historic properties. 335 The rule provides two options for compliance:

"(1) Submittal of documentation to the EPA Regional Office (and to the relevant tribe for the area where the source is located or locating) that a site-specific assessment conducted by another federal agency has been completed for the specific oil and natural gas activity, and that the owner/operator meets all air quality-related requirements as specified within all documents/approvals obtained through that assessment (these requirements are typically implemented and enforced as conditions of an approved Surface Use Plan of Operations and/or Application for Permit to Drill); or (2) submittal of documentation to the EPA Regional Office (and to the relevant tribe for the area where the source is located or locating) demonstrating that the source has completed the screening processes specified by the EPA for consideration of threatened and endangered species and historic properties and received a determination from the EPA stating that it has satisfactorily completed these processes."336

\footnotetext{
33140 C.F.R. $\$ 49,102$.

${ }^{332}$ Review of New Sources and Modifications in Indian Country, supra note 313, at 56,554.

33381 Fed. Reg. at 35,946.

${ }^{334}$ Review of New Sources and Modifications in Indian Country, supra note 313, at 56,563.

33581 Fed. Reg. at 35,949. 336
} 


\section{§ 4(D). EPA's GHG Reporting Requirements}

The EPA requires oil and natural gas companies to collect and report GHG emissions data for sources emitting 25,000 metric tons per year, or more, of $\mathrm{CO}_{2 \mathrm{e}}{ }^{337}$ The reporting requirements apply to facilities owned or operated by Indian tribes and private oil and gas operations on Indian reservations. ${ }^{338}$ Approximately 2,164 oil and natural gas facilities reported GHG emissions during 2013, but only 503 onshore production facilities reported. ${ }^{339}$ Most production operations do not exceed the 25,000 ton threshold for reporting. The EPA's data for 2014 shows only two facilities on the Uinta Indian Reservation reportingthe Altamont Gas Plant and the Bonanza Power Plant. Beginning January 1, 2016, additional data from gathering and boosting systems, completions and workovers of oil wells using hydraulic fracturing, and blowdowns of gas transmission pipelines must be collected and this information must be reported beginning March 31, 2017. ${ }^{340}$ However, the information concerning GHG emissions from oil and gas production is inadequate for effective policy development. On January 15, 2015, the EPA proposed revisions to the GHG reporting rule. ${ }^{341}$ On May 12, 2016, the EPA issued a draft Information Collection Request to require oil and natural gas companies to provide the information needed to regulate existing sources of methane emissions including underground storage facilities that are not currently regulated. ${ }^{342}$ This could lead to hundreds of thousands of existing oil and gas sources that emit methane being subject to new requirements. ${ }^{343}$ The comment period for this information collection effort ended November 15, 2016, and the EPA's proposal has been subject to criticism from the oil and gas industry. ${ }^{344}$

\footnotetext{
${ }^{337}$ U.S. Envtl. Protection Agency, Mandatory Reporting of Greenhouse Gases: Petroleum and Natural Gas Systems, 75 Fed. Reg. 74,458 (Nov. 30, 2010).

${ }^{338}$ Id. at 74,485-74,486.

339 GHGRP 2013: Petroleum and Natural Gas Systems (2013), EPA, http://www.epa.gov/ghgreporting/ghgrp-2013-petroleum-and-natural-gas-systems (last updated Oct. 6, 2015).

${ }^{340}$ Anthony Adragna, Final EPA Greenhouse Gas Reporting Rule Requires More Data From Oil, Gas Industries, 46 ENV'T REP. (BNA) 3161 (Oct. 23, 2015).

${ }^{341}$ U.S. Envtl. Protection Agency, 2015 Revisions and Confidentiality Determinations for Data Elements Under the Greenhouse Gas Reporting Rule, 81 Fed. Reg. 2535 (Jan. 15, 2016).

${ }^{342}$ U.S. Envtl. Protection Agency, EPA's Actions to Reduce Methane Emissions from the Oil and Natural Gas Industry: Draft Information Collection Request for Existing Sources, https://www3.epa.gov/airquality/oilandgas/may2016/icr-fs.pdf. The draft is available at https://www3.epa.gov/airquality/oilandgas/methane.html ${ }^{343} I d$.

${ }^{344}$ Andrew Childers, Data on Methane Emissions Monitoring Sought as EPA Looks Toward New Rules, 47 ENV'T REP. (BNA) 2185 (July 22, 2016; Bridget DiCosmo, Energy Groups Cite Data Collection Challenges In Call For Narrow EPA ICR, 27 Clean Air Rep. (INSIDE EPA) 16:15 (AUG. 11, 2016)
} 


\section{$\S 4(E)$. Bureau of Land Management Regulations}

The Bureau of Land Management carries out the regulatory duties of the Secretary of the Interior in regard to the 56 million acres of Indian mineral estates based on the Indian Mineral Leasing Act and other laws. ${ }^{345}$ Approval of the federal land managers (FLMs) is required by the FIP prior to an oil and natural gas owner/operator beginning construction. A permit to drill (APD) in Indian country normally is a prerequisite to begin operations. ${ }^{346}$ This authorization will include a NEPA review by agencies within the U.S. Department of the Interior. Under this review process, the Bureau of Land Management (BLM) is typically responsible for authorizing mineral rights and the Bureau of Indian Affairs (BIA) authorizes surface activities (i.e., preparing the site for welldrilling activities and operating equipment for the production of oil and/or natural gas). BLM and BIA often enter into agreements designating one agency to take the lead in the NEPA review process regarding the potential impacts of subsurface and surface activities.

These government actions also trigger the need to comply with the Endangered Species Act (ESA) and the National Historic Preservation Act (NHPA). ${ }^{347}$ Compliance with the ESA involves the U.S. Fish and Wildlife Service field offices assessing the impacts to threatened and endangered species and critical habitats, which results in measures implemented to protect those resources that are incorporated in the FLMs' authorization. Historic property impacts are evaluated by State and/or Tribal Historic Preservation Offices, and FLMs must require appropriate measures to protect historic property. ${ }^{348}$

BLM on March 20, 2015, released its final rule concerning hydraulic fracturing activities on tribal lands. ${ }^{349}$ This rule updates a regulatory program that has existed for many years. Most of the rule is aimed at protecting land, water and wildlife from the adverse impacts of fracking, but compliance with the CAA is required. Indian tribes can request a variance from the provisions if they have an equal or more protective regulation. ${ }^{350}$ On February 8, 2016, the BLM proposed regulations that would update the provisions that are more than 30

\footnotetext{
${ }^{345}$ Press Release, U.S. Dept. of Interior, Interior Department Releases Final Rule to Support Safe, Responsible Hydraulic Fracturing Activities on Public Lands (Mar. 20, 2015), https://www.doi.gov/news/pressreleases/interior-department-releases-final-rule-to-support-saferesponsible-hydraulic-fracturing-activities-on-public-and-tribal-lands.

${ }^{346}$ Marc Humphries, Cong. Research Serv., R42432, U.S. Crude Oil and Natural Gas Production IN FEDERAL AND NON-FEDERAL AREAS 7 (2013).

${ }^{347} 80$ Fed. Reg. 56,554, 56,566 (Sept. 18, 2015).

${ }^{348} \mathrm{Id}$.

${ }^{349}$ Land Management Bureau, Oil and Gas; Hydraulic Fracturing on Federal and Indian Lands, 80 Fed. Reg. 16,128 (Mar. 26, 2015); corrected at 80 Fed. Reg. 16,577 (Mar. 30, 2015).

35043 C.F.R. § 3162.3-3(k).
} 
years old concerning natural gas venting, flaring, and royalty free gas. ${ }^{351}$ The proposed rule would require oil and gas producers to limit flaring at oil wells on public and tribal lands. They require inspection for leaks and the replacement of outdated equipment that vent large quantities of gas. Venting from storage tanks will have new limits, and best practices must be utilized to limit gas losses when removing liquids from wells. The proposal also clarifies when operators owe royalties on flared gas and authorizes BLM to set royalty rates above 12.5 percent of the value of the production. ${ }^{352}$ Colorado, North Dakota, Utah, Wyoming and other plaintiffs, including the Ute Tribe, were challenging BLM's authority to regulate fracking. The Ute Tribe also argued that even if BLM has the authority to regulate fracking on federal land the power does not extend to land held in trust for Indian tribes. ${ }^{353}$ In addition, Republican senators were claiming the BLM lacks the authority to regulate methane emissions. ${ }^{354}$ On June 21, 2016, the Federal District Court for Wyoming held that BLM lacks Congressional authority to promulgate regulations to regulate hydraulic fracturing and the Fracking Rule is unlawful. ${ }^{355}$ The case was appealed to the $10^{\text {th }}$ Circuit on June 29,2016 , and oral arguments were held August 12, 2016.356

\section{$\S 5$. Air Pollution Control in Utah's Indian Country}

The federal government exercises its trust responsibilities in Indian country through the BIA within the Department of the Interior. ${ }^{357}$ Much of its work is done through the twelve regional offices. ${ }^{358}$ The Western Region, located in Phoenix, Arizona services approximately 143,000 American Indians in fortytwo tribes located in Arizona (excluding the Navajo Nation), Nevada and Utah

\footnotetext{
${ }^{351}$ Bureau of Land Management, Waste Prevention, Production Subject to Royalties, and Resource Conservation, 81 Fed. Reg. 6616 (Feb. 8, 2016). The comment period was extended at 81 Fed. Reg. 19,110 (Apr. 4, 2016).

${ }^{352}$ U.S. Dept. of the Interior, Press Releases, Secretary Jewell Announces Proposal to Reduce Methane Emissions, Wasted Gas on Public, Tribal Lands 3 (Jan. 22, 2016).

${ }^{353}$ Ben Neary, Future of U.S. fracking regulations in hands of federal judge in Wyoming, SALT LAKE TRIB. Apr. 22, 2016, at B5.

${ }^{354}$ Renee Schoof, Sen. Barrasso Saus BLM Lacks Authority To Cut Gas Waste on Public, Tribal Lands, 47 ENV'T REP. (BNA) 1178 (Apr. 15, 2016); Alan Kovski, Wisdom, Legality of BLM Gas Flaring Rule Argued in Hearing, Public Comment Filing, 47 ENV'T REP. (BNA) 1334 (Apr. 29, 2016).

${ }^{355}$ State of Wyoming v. U.S. Dept. of the Interior, 2016 WL 3509415 (June 21, 2016).

${ }^{356}$ Alan Kovski, Court Improperly Blocked New Rules For Fracking on Federal Lands: Interior, 47 ENV'T REP. (BNA) 2468 (Aug. 19, 2016) [discussing Wyoming v. Jewell, 10 ${ }^{\text {th }}$ Cir, No. 16-8068].

${ }^{357}$ See generally Who We Are, U.S. DEP'T INTERIOR, http://www.bia.gov/WhoWeAre/index.htm (last visited Feb. 19, 2016) (noting that the BIA is "responsible for the administration and management of 55 million surface acres and 57 million acres of subsurface minerals estates held in trust by the United States for American Indian, Indian tribes, and Alaska natives.”).

${ }^{358}$ Regional Offices, U.S. DEP'T INTERIOR, http://www.bia.gov/WhoWeAre/RegionalOffices/index.htm (last visited Feb. 19, 2016).
} 
and portions of California, Oregon and Idaho. ${ }^{359}$ The regions have agencies located in their service area to serve specific tribes.

There are six federally recognized Indian tribes in Utah and a small band of Colorado's Ute Mountain Tribe, but only two of the tribes have significant sources of air pollutants. ${ }^{360}$ The Confederated Tribes of the Goshute Reservation, Ibapah, UT, 84034 is located in western Utah and covers approximately 112,000 acres. ${ }^{361}$ The tribe does not appear to have any significant air emission sources. ${ }^{362}$ The Skull Valley Indian Community (Goshute), Grantsville, UT, 84029 is located in northwestern Utah and is approximately 17,248 acres. ${ }^{363}$ As of 2009 there were about 500 Goshutes in the two Goshute tribes. ${ }^{364}$ In 1976 the Skull Valley Band of Goshutes built a rocket motor testing facility that was leased to Hercules, Inc. ${ }^{365}$ The facility shut down in the mid-1990s, and there are no existing or planned sources of air pollution on the Skull Valley reservation. ${ }^{366}$ However, some of the Skull Valley Goshutes tried to allow their reservation to be used for depositing nuclear waste, which became controversial. ${ }^{367}$ The Confederated Tribes of the Goshute Reservation were among the groups opposed to the waste facility. ${ }^{368}$ The efforts to site the waste facility were ultimately unsuccessful.

The Paiute Indian Tribe consists of five bands that live on five reservations in Southwestern Utah with headquarters in Cedar City, UT, 84720.369 The Paiutes lost most of their land and population in the period from the mid-1800s through 1980. Legislation enacted on February 17, 1984, restored some of the land. 370

\footnotetext{
${ }^{359}$ Western Region Overview, U.S. DEP'T INTERIOR, http://www.bia.gov/WhoWeAre/RegionalOffices/Western/index.htm (last visited Feb. 19, 2016).

${ }^{360}$ In addition, the White Mesa Utes that are part of the Ute Mountain Tribe located in Tawaoc, Colorado have a settlement of 380 members located eleven miles south of Blanding, Utah.

${ }^{361}$ Frequently Asked Questions, UTAH AM. Indian Digital ARCHIVE, http://utahindians.org/archives/faq.html (last visited Feb. 19, 2016).

${ }^{362}$ Efforts to contact the Confederated Tribes failed. The Utah Division of Indian Affairs had no information on air emission sources on the tribe's reservation.

${ }^{363}$ The history of the Skull Valley Goshutes is discussed in Lincoln L. Davies, Skull Valley Crossroads: Reconciling Native Sovereignty and the Federal Trust, 68 MD. L. REV. 290 (2009).

${ }^{364}$ The Goshutes: Did you Know, UTAH AM. InDiAn Digital ARCHIVE, http://utahindians.org/archives/goshute/didYouKnow.html (last visited Dec. 1, 2015).

${ }^{365}$ History: The Goshutes, UTAH AM. INDIAN DigITAL ARCHIVE, www.utahindians.org/archives/goshutes/history.html (last visited Dec. 1, 2015).

${ }^{366}$ E-mail from Candace Bear, Tribal Chairperson, to author (Dec. 22, 2015) (on file with author).

${ }^{367}$ See, e.g., Judy Fahys, Utah N-Waste Site Backers Call it Quits, SALT LAKE TriB. (Dec. 21, 2012), http://archive.sltrib.com/story.php?ref=/sltrib/politics/55513674-90/consortium-friday-license-nrc.html.csp. For documents concerning the spent fuel storage installation, see UTAH DEP'T ENVTL. QUALITY, www.deq.utah.gov (last visited Dec. 14, 2015).

${ }^{368}$ Resolution of the Governing Body of the Confederated Tribes of the Goshute Reservation, Res. No. $97-$ G-022, http://www.deq.utah.gov/Pollutants/H/highlevelnw/opposition/docs/2005/09Sep/goshutetribes.pdf (last visited Feb. 19, 2016).

${ }^{369}$ Paiutes: Did You Know?, UtAh Am. Indian Digital ArChive, www.utahindians.org/archives/paiutes/didYouKnow.html (last visited Dec. 1, 2015).

${ }^{370}$ History: The Paiutes, UtAH AM. Indian Digital ARCHIVE, www.utahindians.org/archives/paiutes/history.html (last visited Dec. 1, 2015).
} 
Today the Paiute Tribe's reservation has a population of 709 on 32,446 acres scattered through southwestern Utah. ${ }^{371}$ There are no emission sources on the reservation other than homes and vehicles, and there are no air regulations. ${ }^{372}$

The Northwestern Band of the Shoshoni Nation, Brigham City, UT, 84302 is located in northern Utah. Their 187 acres is the smallest reservation in Utah. ${ }^{373}$ In 2013 the tribe had 431 members. ${ }^{374}$ It too appears to have no significant air pollution sources.

The Navajo Nation is the largest Indian reservation in the United States with over 17 million acres and is headquartered in Window Rock, Arizona, 86515. The tribal lands extend into New Mexico and southeastern Utah. ${ }^{375}$ The tribe has over 250,000 members and 7,000 live in Utah. ${ }^{376}$ The Nation has an environmental protection agency with 65 staff members. The Nation enacted a comprehensive Air Pollution Prevention and Control Act in 2004. ${ }^{377}$ The Navajo EPA has been delegated the authority to administer the Part 71, Title V program for major facilities, for which the Nation has promulgated operating permit regulations. ${ }^{378}$ There have been 14 Title $\mathrm{V}$ permits issued to facilities operating on the Navajo Nation. ${ }^{379}$ The Nation also has been delegated significant authority over inspections and civil enforcement. ${ }^{380}$

Petroleum development began on the Navajo Nation in the 1920s. In 1933 Congress enlarged the Navajo Nation to add the Aneth Extension located in southeast Utah. In 1956 oil was discovered in the Aneth field and 577 wells have since been drilled, which resulted in the production of 428 million barrels of oil. ${ }^{381}$ The field has three units operated by Resolute Energy Corporation, which

${ }^{371}$ Paiute Tribe, InDIAN EDUC., http://www.uen.org/indianed/utahtribes/paiute.shtml (last visited Dec. 21, 2015).

${ }^{372}$ E-mail from Gaylord Robb, Paiute Gov't, to author (Dec. 21, 2015) (on file with author).

${ }^{373}$ Did Your Know: The Shoshone, UtAH AM. InDIAn Digital ARChIVE, www.utahindians.org/archives/shoshone/didYouKnow.html (last visited Dec. 1, 2015).

${ }^{374} \mathrm{http} / / / \mathrm{www} . u t a h i n d i a n s . o r g /$ archives/faq.html.

${ }^{375}$ One of the Navajo Nation's major sources of air pollutants is the Four Corners Power Plant located on the Navajo Nation near Shiprock, New Mexico. Arizona Public Service Company and the other owners in 2015 agreed in a consent decree to spend $\$ 160$ million over the nest four years to reduce air pollution. Carolyn Whetzel, Owners of Four Corners Power Plant Agree To Spend \$160 Million to Reduce Emissions, 46 ENV'T REP. (BNA) 1927 (June 26, 2015).

${ }^{376}$ Frequently Asked Questions, supra note 14.

377 See Navajo Nation Air Pollution Prevention and Control Act (2004), http://www.navajonationepa.org/Pdf\%20files/NNAQCP-NavajoNationCleanAirAct_Final.pdf.

${ }^{378}$ Navajo Nation Envtl. Protection Agency, Navajo Nation Air Quality Control Program Operating Permit Regulations (July 8, 2004); Navajo Nation Envtl. Protection Agency, Navajo Air Quality Program, Program Description and Transition Plan for A Delegated Part 71 Program 6 (July 16, 2004).

379 Operating Permit Program, Navajo EPA, http://www.navajonationepa.org/opp/index.html (last visited Dec. 16, 2015).

${ }^{380}$ Jill E.Grant, Enforcing Tribal Environmental Laws without "Treatment as a State, NAT. RES. \& ENV'T 1 (Winter 2016).

${ }^{381}$ About NNOGC, NAVAJO NATION OIL \& GAS CO., http://www.nnogc.com/about-us.html (last updated Aug. 8, 2013). 
owns the controlling interest in the field. ${ }^{382}$ In 1993 the Navajo Nation Oil and Gas Co., Inc. (NNOGC) was created, and in 1998 it became a federally chartered corporation pursuant to the Indian Reorganization Act. ${ }^{383}$ NNOGC operates an 87-mile pipeline, distributes and markets fuel, and in 2012 purchased a 10 percent interest in Resolute's Greater Aneth Field. ${ }^{384}$ Both oil and gas are produced from the Aneth field, but oil production dominates. ${ }^{385}$ One of the units, the McElmo Creek Unit, has a PSD permit pending at EPA's Region 9.386

The Navajo Nation issued a Part 71 permit to the Resolute Natural Resources Company on July 30, 2007, which expired July 30, 2012.387 Resolute submitted a timely permit renewal application and is allowed to continue to operate under their existing permit. ${ }^{388}$ On August 16, 2012, the EPA promulgated rules on oil and gas operations, and on December 31, 2014, the Agency issued final revisions to the rules. ${ }^{389}$ Resolute expects that they will need to modify their operations in order to comply, which will entail increased capital and operating costs. ${ }^{390}$

The Uintah and Ouray Reservation, Fort Duchesne, UT, 84026 is located in the Uintah Basin in northeastern Utah approximately 150 miles east of Salt Lake City. ${ }^{391}$ The Northern Ute Tribe (Utes) resides on the reservation. It is comprised of three bands: the White River Band, Uncompahgre Band, and the Uintah Band. The reservation was the original home of the Uintah Band, but later the Whiteriver Band and the Uncompahgre Band were removed from Colorado and settled in the present Uintah \& Ouray Reservation. ${ }^{392}$ There are 2,970 Ute Indians with over half the members living on 1.3 million acres of trust land..$^{393}$

\footnotetext{
${ }^{382}$ Aneth Field, RESOLUTE ENERGY CORP., http://www.resoluteenergy.com/aneth_field.html (last visited Jan. 5, 2016).

${ }^{383}$ About NNOGC, supra note 359.

${ }^{384} \mathrm{Id}$.

385 Aneth Field, supra note 360; see also RESOLUTE ENERGY CORPORATION 2014 ANNUAL REPORT 3 (May 11, 2015) [hereinafter RESOLUTE ANNUAL REPORT], http://www.resoluteenergy.com/downloads/2014\%20Resolute\%20bookmarked\%20annual.pdf.

${ }^{386}$ RESOLUTE ANNUAL REPORT, supra note 385, at 16; see also Prevention of Significant Deterioration (PSD) Permits Issued by Region 9, EPA, http://www.epa.gov/caa-permitting/prevention-significantdeterioration-psd-permits-issued-region-9 (last visited Feb. 19, 2016) (listing pending PSD permits).

${ }^{387}$ Navajo Nation Envtl. Prot. Agency, Title V Permit to Operate, Permit \# NN-OP 00-02 (July 30, 2007), http://www.navajonationepa.org/airqty/Pdf_files/R\%20A\%20U\%20final\%20permit\%2007-20-07.pdf.

${ }^{388}$ E-mail from Justina B. George, Envtl. Specialist, NNEPA, to Sheena M. Christman, Research Assistant, S.J. Quinney Coll. of Law (Feb. 2, 2016, 9:05 AM) (on file with author).

${ }^{389}$ U.S. Envtl. Protection Agency Oil and Natural Gas Sector: Reconsideration of Additional Provisions of New Source Performance Standards, 79 Fed. Reg. 79,018 (Dec. 31, 2014).

${ }^{390}$ RESOLUTE ANNUAL REPORT, supra note 364, at 17.

${ }^{391}$ Ute Tribe Location, UTE INDIAN TRIBE, http://www.utetribe.com/ (last visited Feb. 19, 2016).

${ }^{392}$ Short History, UTE INDIAN TRIBE, www.utetribe.com/departments/public-relations.html (last visited Jan. 16, 2016).

${ }^{393}$ About the Utes, UTE INDIAN TRIBE, www.utetribe.com (last visited Dec.16, 2015)
} 
The Uintah \& Ouray Reservation covers 4.5 million acres in Utah, which makes it the second largest Indian Reservation in the United States. ${ }^{394}$ The Reservation contains land owned by the Northern Ute Tribe, Ute Indian Allocated lands, lands jointly managed by Ute Indian Tribe and Ute Distribution Corporation, privately owned lands, and federal mineral estates. ${ }^{395}$ In the Uintah Basin the Ute Indian Tribe controls about one-third of the mineral estates underlying the surface estates owned by the Tribe. ${ }^{396}$

The Ute Indian Tribe leases about 400,000 acres for oil and gas development, which results in about 7,000 wells producing 45,000 barrels of oil and 900 million cubic feet of gas per day. In the Uinta Basin approximately three quarters of the gas production and half the oil production is from Indian country. ${ }^{397}$ In 2014 the Ute Indian tribe announced a plan to build a 1,000 megawatt natural gas-fired electric generating plant on the Uintah and Ouray Reservation to utilize the available fuel. ${ }^{398}$ Oil and natural gas wells are regulated by the BLM based on the Indian Mineral Leasing Act, with regulations that are uniform for all federal lands. ${ }^{399}$ This means that drilling permits are subject to BLM's 49-step process and a fee of $\$ 6,500$ or more for each well. ${ }^{400}$ For this reason some tribal leaders believe much of the growth in oil and gas production in Utah has occurred on state or private lands, which is an issue of concern to the Utes. ${ }^{401}$

The Northern Ute Indian Tribe has TAS status. ${ }^{402}$ However, the EPA issues the Title $V$ operating permits on the Uintah \& Ouray Indian Reservation. There are ten Title $V$ permits on the reservation, which is more than 20 percent of the permits issued nationwide. ${ }^{403}$ There are nine operating permits for the gas industry; eight are for compressor stations. ${ }^{404}$ There are no PSD permits for oil

\footnotetext{
${ }^{394}$ Frequently Asked Questions, supra note 14.

${ }^{395}$ UINTAH AND OURAY RESERVATION 1, www.eere.energy.gov/tribalenergy/guide/pdfs/uintah_ouray.pdf (last visited Jan. 16, 2016).

${ }^{396}$ Bureau OF Indian AfFAirs, DeP'T OF THE InTERIOR, Mineral \& Mining DeVElopment Guide: “How TO DO BUSINESS ON THE UINTAH \& OURAY RESERVATION” 2-3 (2006).

${ }^{397}$ Uinta Basin: Ozone in the Uinta Basin, UTAH DEP'T OF ENVTL. QUALITY, http://www.deq.utah.gov/locations/U/uintahbasin/ozone/overview.htm (last visited Feb. 19 2016).

${ }^{398}$ Ute Indian Tribe Looks to Build 1,000 MW Gas-Fired Power Station, PENN ENERGY (May 28, 2014), http:/www.pennenergy.com/articles/pennenergy/2014/05/ute-indian-tribe-looks-to-build-1-000-mw-gasfired-power-station.html.

39952 Stat 347, ch.198 (May 11, 1938), 25 U.S.C. 396a et seq.

${ }^{400}$ Kemp, supra note 6.

${ }^{401} I d$.

402 See supra note 190 and accompanying text.

${ }^{403}$ E-mail from Regina Chappell, supra note 194.

${ }^{404}$ Chipeta Processing LLC - Chipeta Gas Plant; Chipeta Processing LLC - Natural Buttes Compression Station; Wind River Resources Company - North Hill Creek Compressor Station; Monarch Natural Gas LLC - Riverhead Compressor Station; QEP Field Services - Chapita Compressor Station; QEP Field Services - Coyote Wash Compressor Station; QEP Field Services - Wonsits Valley Compressor Station; QEPM Gathering LLC - Island Compressor Station; Deseret Power Electric Cooperative - Bonanza Power Plant and Questar Pipeline Company - Fidlar Compression Station.
} 
and gas industry sources, despite the reservation's importance in the production of this energy resource. Because the Basin has not yet been designated nonattainment for ozone there are no nonattainment new source review permit requirements. There is only one synthetic minor source-a gas processing plant. There are no general permits. The CAA requirements aimed at major sources are of limited applicability because the oil and gas industry minimizes the sources subject to the requirements, thus emissions from existing oil and gas wells have been largely unregulated.

To determine whether a source is major for a determination under the Title V operating permit program, or the PSD or NSR non-attainment programs, the emissions from multiple wells are aggregated for the purpose of regulation if they are physically adjacent. 405 By separating wells they avoid aggregation. The EPA attempted to regulate wells based on their functional relatedness, but the Agency lost in the Sixth Circuit. ${ }^{406}$ Its efforts to limit the decision to the Sixth Circuit's jurisdiction also failed. ${ }^{407}$ The EPA in 2016, as previously discussed, announced a new source determination rule that would aggregate wells within $1 / 4$ mile. ${ }^{408}$

\section{$\S$ 6. Utah's Uinta Basin}

The Uinta Basin, in northeast Utah, is bounded on the north by the Uinta Mountain range, on the south by the Book and Roan Cliffs, on the west by the Wasatch Range, and on the east by the terrain separating it from the Piceance Basin in Colorado. ${ }^{409}$ The floor of the basin is approximately 4,800 feet above sea level. Duchesne and Uintah Counties make up nearly all the Basin. ${ }^{410}$ The Uinta Basin is the center of the state's oil and gas industry where in 2014 there were approximately 8,000 gas wells and 2,000 oil wells in operation. ${ }^{411}$ Most of the oil wells are in Duchesne County and most of the gas wells are in Uintah County. There are also about 1,000 coal bed methane wells and conventional wells in Carbon County. ${ }^{412}$ Approximately two-thirds of the active oil and gas wells, three quarters of the gas production, and half the oil production are located in Indian Country. 413

\footnotetext{
${ }^{405} 40$ C.F.R. $\S 71.2$

${ }^{406}$ Summit Petroleum Corp. v. EPA, 690 F.3d 733 (6th Cir. 2012).

${ }^{407}$ Nat'1 Envtl. Dev. Ass'n Clean Air Project v. EPA, 752 F.3d 999 (D.C. Cir. 2014).

${ }^{408}$ See fn 306 and the associated text.

${ }^{409}$ ENVIRON, FINAL REPORT: 2014 UINTA BASIN WinTER OZONE STUDY 2-1 (2015),

http://www.deq.utah.gov/locations/U/uintahbasin/ozone/docs/2015/02Feb/UBWOS_2014_Final.pdf.

${ }^{410} I d$.

${ }^{411}$ C. Warneke et al., Volatile Organic Compound Emissions from the Oil and Natural Gas Industry in the Uintah Basin, Utah: Oil and Gas Well Pad Emissions Compared to Ambient Air Composition, 14 ATMOSPHERIC CHEMISTRY \& PHYSICS 10,977 (2014).

${ }^{412} I d$.

${ }^{413}$ Uinta Basin: Ozone in the Uinta Basin, supra note 375.
} 
During the summer, atmospheric ozone levels in the western United States approach the ozone NAAQS even in remote rural areas. ${ }^{414}$ Rural ozone air pollution has not been the subject of much study. It was only since 2010 that high ozone levels in the winter were found in the Upper Green River Basin in Wyoming and in the Uintah Basin. ${ }^{415}$ With the rapid increase in oil and gas production in the rural West and the associated air pollution winter ozone has become a subject of increased monitoring and research projects. ${ }^{416}$

The chemistry of winter ozone formation differs from summer ozone formation and is only beginning to be understood. ${ }^{417}$ The most important precursor appears to be carbonyl emissions, such as aldehyde, keytone and ester, emitted by oil and gas operations, especially when a well is drilled. ${ }^{418}$ The primary cause of high ozone concentrations is wintertime temperature inversions, but clouds, wind, snow depth, and the reflectivity of snow affect ozone concentrations. ${ }^{419}$ During inversion conditions in the winter of 2013-2014 the 8hour ozone standard of 75 parts per billion (ppb) average was exceeded at twelve of 18 monitoring locations in the Uinta Basin. The ozone standard is now $70 \mathrm{ppb}$. But, during the winter of 2012, one of the warmest winters on record, the ozone standard was not exceeded. ${ }^{420}$

The high ozone levels led the Northern Ute Indian Tribe's Air Quality Department to work in cooperation with the EPA, the National Park Service (NPS), and Utah to monitor ozone at locations in the Uintah Basin at Myton, White Rocks, Ouray, and Redwash. Utah's Division of Air Quality (DAQ) has monitors in Roosevelt and Vernal. The National Park Service has monitors in Dinosaur National Park and BLM has monitors in Fruitland. ${ }^{421}$ In addition, Utah's Division of Air Quality has an Oil and Gas Quality Partnership with industry, including Ute Energy, to evaluate the impact of oil and gas development on air quality.

The EPA and the Ute Tribe of the Uintah and Ouray Reservation have regulatory authority for air pollution control in Indian country. The BLM has

\footnotetext{
${ }^{414}$ Arnold W. Reitze, Jr., The National Ambient Air Quality Standards for Ozone, 6 ARIZ. J. ENVTL. L. \& POL'Y (2015).

${ }^{415}$ Utah Division of Air Quality, Air Quality Research Projects 15 (Jan. 2016).

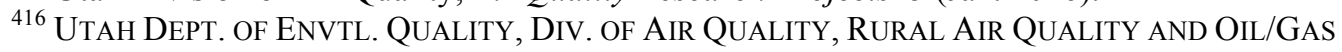
DEVELOPMENT IN UtAh FACT SHEET 2 (2010) [hereinafter OiL/GAS FACt SHEET], http://www.deq.utah.gov/Topics/FactSheets/docs/June2010_Air_Issues.pdf.

${ }^{417}$ ENVIRON, supra note 2.

${ }^{418}$ Air Quality Research Projects 16-17, supra note 394.

${ }^{419}$ Id. at 4 .

${ }^{420}$ Utah Dept. of Envtl. Quality, Uintah Basin: Air Quality and Energy Development (2016).

${ }^{421}$ Utah Dept. of Envtl. Quality, Uintah Basin: Ozone in the Uinta Basin: Strategies and Tactics, http://www.deq.utah.gov/locations/U/uintahbasin/ozone/strategies/strategies.htm (last visited Feb. 19, 2016); Air Quality Department, UTE INDIAN TRIBE, http://www.utetribe.com/departments/air-quality.html (last updated June 18, 2014).
} 
responsibility for permitting and overseeing 11,000 oil and gas operations in the Uintah Basin. ${ }^{422}$ On the non-federal lands in the Basin, the Utah Division of Air Quality (DAQ) handles the permitting of oil and gas operations that is coordinated with the Utah Division of Oil, Gas, and Mining (DOGM), which regulates oil and gas activities through the use of drilling permits. ${ }^{423} \mathrm{New}$ or modified sources subject to DAQ/DEMG's authority must obtain an approval order to ensure there is no increase in the ozone level in the Basin. Sources subject to Utah's regulation that emit less than five tons per year of any criteria pollutant, or less than 500 pounds of any single hazardous air pollutant, or less than 2,000 pounds of all hazardous air pollutants are not subject to the NSR program. ${ }^{424}$ Many emission sources in the oil and gas industry are below this de minimus threshold for NSR permitting. Moreover information concerning oil and gas operations has been inadequate for effective regulation. ${ }^{425}$

The State of Utah and the Ute Tribe of the Uintah and Ouray Reservation are participating in the Ozone Advance program to reduce emissions of ozone precursors with the primary focus being VOC emission reductions to avoid the Basin being designated as an ozone nonattainment area. ${ }^{426}$ This is unlikely to succeed. Uintah County is expected to be designated a moderate nonattainment area and Duchesne County is expected to be designated a marginal nonattainment area based on the 2008-8-hour ozone standard of $75 \mathrm{ppb}$. This will require SIP revisions to impose more stringent requirements on existing sources.427 The requirements will include the need to install reasonably available control technology (RACT) at existing sources, and the EPA announced the release of draft control techniques guidelines to control VOCs on September 18, $2015 .{ }^{428}$ On October 1, 2015, the EPA lowered the ozone standard to $70 \mathrm{ppb}, 429$ which is expected to lead to additional emissions controls on existing sources including existing oil and gas operations. ${ }^{430}$

While EPA and Utah work to reduce emissions from oil and gas operations in the Uintah Basin, the BLM is dealing with a proposal by Crescent Point Energy, a Canadian company, that is seeking approval to drill up to 3,925 wells in a 35 mile swath across the basin. The project will include 863 miles of new roads, 170

\footnotetext{
${ }^{422}$ Brian Maffly, State goes after idle wells on federal leases, SALT LAKE TRIB. , June 10, 2016, at A1

${ }^{423}$ Uinta Basin: Ozone in the Uinta Basin, supra note 375.

${ }^{424}$ Utah Regulation R307-401-9.

${ }^{425}$ OIL/GAS FACT SHEET, supra note 395, at 5.

${ }^{426}$ Uinta Basin: Ozone in the Uinta Basin, supra note 375.

${ }^{427}$ U.S. Envtl. Protection Agency, Implementation of the 2008 National Ambient Air Quality Standards for Ozone: State Implementation Plan Requirements, 80 Fed. Reg. 12,264 (Mar. 6, 2015).

${ }^{428}$ U.S. Envtl. Protection Agency, Release of Draft Control Techniques Guidelines for the Oil and Gas Industry, 80 Fed. Reg. 56,577 (Sept. 18, 2015).

${ }^{429}$ U.S. Envtl. Protection Agency, National Ambient Air Quality Standards for Ozone, 80 Fed. Reg. 65,292 (Oct. 26, 2015).

${ }^{430}$ Bridget DiCosmo, Scope of Draft EPA Emissions Guide for Drilling Hinges On Ozone NAAQS, 26 CleAn AIR ReP. (Inside EPA) 18:3 (Aug. 27, 2015); Air Quality Research Projects, supra note 384, at 3 (Jan. 2016).
} 
miles of cross-country pipelines, five salt water disposal wells, five facilities to treat "produced" waste water, four gas-processing plants, and other support facilities. ${ }^{431}$

\section{§ 7. Conclusion}

Environmental law applicable to Indian lands is similar to the laws applicable throughout the nation, but with significant differences. States play a very limited role in regulating sources of emissions in Indian lands. The EPA has the major responsibility for controlling air pollution, but its efforts to-date are inadequate. The CAA gives tribes the power to regulate air pollution, but only a few tribes, such as the Navajo Nation, have the resources to utilize this power. Voluminous federal regulations are aimed primarily at new sources, while existing sources have much less oversight, although this may be changing. The inability of the federal and state governments to effectively aggregate oil and gas operations in order to impose major source requirements has left important sources of rural air pollution to be minimally regulated. The new and pending regulations as well as the potential designation of lands used for oil and gas production as nonattainment areas may bring needed controls. But trying to effectively regulate an industry suffering from effects of low energy prices will be a challenge.

${ }^{431}$ Brian Maffly, BLM pitches a massive Uinta Basin drilling plan, SALT LAKE TRIB., Apr. 9, 2016, at A1. 